University of Miami Law School University of Miami School of Law Institutional Repository

Articles

Faculty and Deans

2014

\title{
Pensioners, Bondholders, and Unfair Discrimination in Municipal Bankruptcy
}

Andrew B. Dawson

University of Miami School of Law, adawson@law.miami.edu

Follow this and additional works at: https://repository.law.miami.edu/fac_articles

Part of the Bankruptcy Law Commons, and the Labor and Employment Law Commons

\section{Recommended Citation}

Andrew B. Dawson, Pensioners, Bondholders, and Unfair Discrimination in Municipal Bankruptcy, 17 U. Pa. J. Bus. L. 1 (2014).

This Article is brought to you for free and open access by the Faculty and Deans at University of Miami School of Law Institutional Repository. It has been accepted for inclusion in Articles by an authorized administrator of University of Miami School of Law Institutional Repository. For more information, please contact library@law.miami.edu. 


\title{
PENSIONERS, BONDHOLDERS, AND UNFAIR DISCRIMINATION IN MUNICIPAL BANKRUPTCY
}

\author{
Andrew B. Dawson $\dagger$
}

Detroit recently confirmed its plan of debt adjustment under which the city has endeavored to adjust its pension obligations. The court's confirmation order and oral opinion on the record present what is perhaps the most significant decision regarding a key question facing any city attempting to adjust pensions in bankruptcy: can a city propose to pay its pension claimants significantly more than its other unsecured creditors? This question involves interpreting the Bankruptcy Code's unfair discrimination rule.

The Detroit bankruptcy court applied a novel interpretation of unfair discrimination, eschewing the relatively thin body of case law interpreting this rule, and suggesting that the rule should have a municipal bankruptcyspecific meaning.

This article contends that there is no need for such a specialized interpretation of unfair discrimination. Many of the factors that motivated the court's departure from the case law can actually be addressed more effectively under the case law developed for corporate reorganization. Adhering to the corporate reorganization statute has statutory and historical support. Further, such a rule would provide a more workable structure for determining when discrimination is unfair.

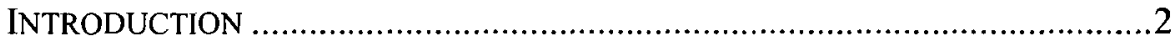

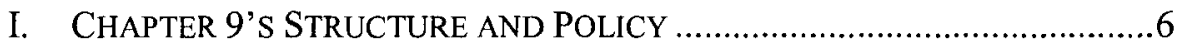

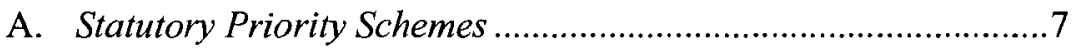

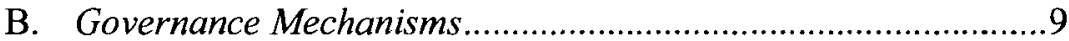

II. FUNCTION OF THE UNFAIR DISCRIMINATION RULE .............................13

A. Development of Unfair Discrimination Rule .............................14

B. Vertical vs. Horizontal Protections ...........................................16

$\dagger$ Associate Professor, University of Miami School of Law. I would like to thank Pamela Foohey, Melissa Jacoby, and Chrystin Ondersma for helpful comments, Bianca Anderson and the library staff at the University of Miami School of Law provided excellent support, and George Bugg and Kayleigh McEnany for careful research assistance. All errors are my own. 


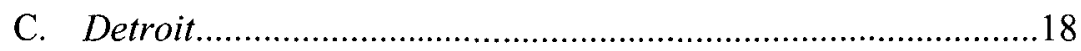

III. THE UNFAIR DISCRIMINATION RULE'S MEANING................................20

A. Chapter IX: Avon Park and Paradise Irrigation .........................20

1. Avon Park, Florida...........................................................21

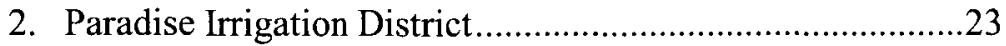

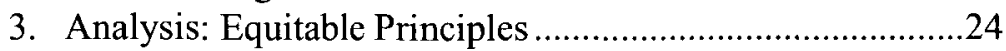

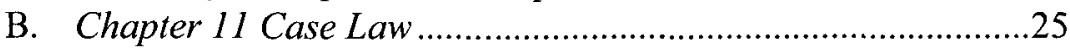

1. Chapter 13-Derived Four-Factor Test................................27

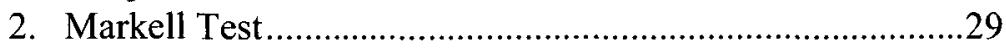

3. Analysis: "Necessity" and "New Value"..............................32

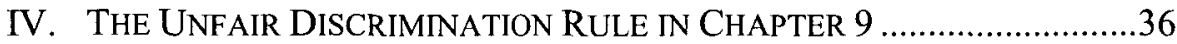

A. No Special Chapter 9 Unfair Discrimination Rule.....................36

B. Fairness and Mission-Based Concerns in the Markell Test .......39

C. Application to Detroit ................................................................42

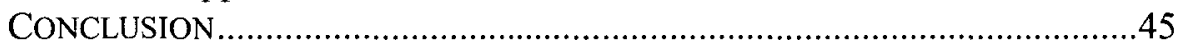

\section{INTRODUCTION}

Unfunded pension obligations are the major story in municipal financial distress, as cities struggle to meet their pension obligations while still meeting their other debt obligations, investing in infrastructure improvements, and providing services to residents. ' States face significant obstacles in addressing the problem of underfunded pensions on their own. ${ }^{2}$ Not only do states face the usual Contracts Clause constraints on impairing contractual obligations, but some states give constitutional protection to pension obligations. ${ }^{3}$

1. See, e.g., Reid Wilson, Chicago's Mind Blowing $\$ 33$ Billion Debt and Pension Obligations, THE WASHINGTON POST (Nov. 18, 2013), http://www.washingtonpost.com/ blogs/govbeat/wp/2013/11/18/chicagos-mind-blowing-33-billion-debt-and-pensionobligations/ (describing Chicago's challenge of properly funding its pensions); see also A Widening Gap in Cities: Shortfalls in Funding for Pensions and Retiree Health Care, PEw CENTER (Jan. 2013), http://www.pewstates.org/uploadedFiles/PCS_Assets/2013/ Pew_city_pensions_report.pdf (reporting that the largest 61 cities in the United States had pension shortfalls of $\$ 99$ billion in fiscal year 2009 , a number which increased $15 \%$ among the 40 reporting cities in 2010).

2. Amy Monahan, Public Pension Plan Reform: The Legal Framework, 5 EDUCATION, FINANCE \& POLICY 617, 617 (2010), available at http://ssrn.com/abstract=1573864 (providing "an overview of the legal limitations on the ability of states to amend their existing pension plans with respect to current participants.").

3. Id., (listing Alaska (Alaska CONST. art. XII, \& 7), Arizona (ARIZ. CONST. art. XXIX, § 1), New York (N.Y. ConST. art. V, § 7) and Illinois (ILL. ConsT. art. XIII, § 5) as examples). As described below, Michigan likewise has such a constitutional pension protection. 
Faced with the prospect of defaulting on bond obligations, driving out residents by imposing even higher property taxes, and cutting important services, municipalities have looked to Chapter 9 of the Bankruptcy Code ${ }^{4}$ as a means to adjust their pension obligations. Most notably, the City of Detroit's bankruptcy filing has brought this issue to the forefront, but it is not alone. Already, the city of Central Falls, Rhode Island, has restructured its pension obligations through Chapter $9,{ }^{5}$ and Stockton, California, considered doing so as well. ${ }^{6}$

In all three of these cities, a major question was whether the city could confirm a plan that provided for a significantly larger recovery for pension claimants than for other unsecured claimants, namely the municipal bondholders. That is, even if pension claims have the same distribution priority as bondholders and other unsecured claimants, can the city nevertheless favor pensioners over other claimants (or vice versa)? Bankruptcy law permits a debtor to separately classify creditors, with each class of creditors entitled to vote on the plan. If any class opposes the debtor's plan of adjustment, the court may nonetheless confirm the plan only if it finds that "the plan does not discriminate unfairly, and is fair and equitable, with respect to each class of claims or interests that is impaired under, and has not accepted, the plan."

While the Bankruptcy Code goes on to define what is included in the "fair and equitable" requirement, the Code does not explain the meaning of "discriminate unfairly." "Until recently, this unfair discrimination rule had not arisen under Chapter 9 and, until the recent municipal bankruptcy filings in Detroit and Stockton, this rule had received very little scholarly attention. ${ }^{9}$

4. 11 U.S.C. $\$ \S 901-946(2010)$. Chapter 9 provides for the adjustment of debts of a "municipality," defined as a "political subdivision or public agency or instrumentality of a State." 11 U.S.C. $\S 101(40)(2010)$.

5. In re Centr. Falls, 468 B.R. 36, 72 (Bankr. D.R.I. 2012).

6. In re Stockton, 493 B.R. 772,777 (Bankr. E.D. Cal. 2013).

7. 11 U.S.C. $\$ 1129(b)(1)(2010)$.

8. 11 U.S.C. $\$ 1129(\mathrm{~b})(2)(2010)$.

9. Richard M. Hynes \& Steven D. Walt, Pensions and Property Rights in Municipal Bankruptcy, 33 Rev. BANKING \& FIN. L. 609 (2014) [hereinafter Hynes \& Walt, Pensions \& Property Rights] (analyzing the priority in payment of a municipality's pension obligations); Richard M. Hynes \& Steven D. Walt, Fair and Unfair Discrimination in Municipal Bankruptcy 1 (Virginia Pub. Law \& Legal Theory Research Paper No. 2014-55, 2014), available at http://ssrn.com/abstract=2493529 [hereinafter Hynes \& Walt, Fair \& Unfair Discrimination] (describing the law defining the unfair discrimination standard and the categories of circumstances where discrimintion between co-equal classes is allowed); C. Scott Pryor, Municipal Bankruptcy: When Doing Less is Doing Best, 88 AM. BANKR. L. J. 85, 114 (2014); see also David A. Skeel, JR., Can Pensions Be Restructured iN (DETROIT's) MUNICIPAL BANKRUPTCY? 4 (2013), available at http://www.fedsoc.org/publications/detail/can-pensions-be-restructured-in-detroits-municipal-bankruptcy 
Even though Central Falls, Stockton, and Detroit all ultimately gave superior treatment to some group of claimants relative to other similarly situated claimants, only in Detroit did the court have to squarely confront the unfair discrimination rule. Central Falls effectively paid its bondholders in full while reducing its pension obligations by half, but the pensioners consented to this treatment. ${ }^{10}$ Stockton ultimately declined to impair its pension obligations, effectively paying them in full, while distributing only a negligible amount to other unsecured creditors. "In that case, though, the unsecured creditors were placed in the same class as the pension claimants and that class approved the plan; hence, the unfair discrimination rule did not apply. ${ }^{12}$

Detroit's bankruptcy confirmation, on the other hand, had to address the unfair discrimination rule even after the city had settled with the most vocal plan opponents. The court articulated a novel interpretation of this rule, providing perhaps the most significant such decision since the Supreme Court's depression-era cases of Avon Park ${ }^{13}$ and Paradise Irrigation District. ${ }^{14}$ The court stated that determining whether discrimination among creditor classes is unfair is a matter to be determined according the court's "judgment of its conscience regarding that discrimination." 15

The court's articulation of this rule rejects case law interpreting unfair discrimination in the context of corporate reorganizations under Chapter 11 of the Bankruptcy Code. This departure reflects, in part at least, the court's concern that unfair discrimination be interpreted in light of the purpose of municipal bankruptcy law. Thus, the court considered "mission-related" justification for Detroit's decision to discriminate among classes of unsecured creditors. ${ }^{16}$

(analyzing the legality of restructuring Detroit's bankruptcy).

10. Steven Church \& Steve Ludsin, Central Falls, Rhode Island, Bankruptcy Exit Approved, BloomberG News (Sept. 7, 2012), http://www.bloomberg.com/news/2012-0906/central-falls-rhode-island-bankruptcy-exit-approved.html.

11. Mary Williams Walsh, Judge Approves Bankruptcy Exit for Stockton, Cali., New York Times DeAl Book (October 30, 2014), http://dealbook.nytimes.com/2014/10/30/ judge-approves-bankruptcy-exit-for-stockton-calif/?_r $=0$.

12. Id.

13. Am. United Mut. Life Ins. Co. v. City of Avon Park, Fla., 311 U.S. 138, 141 (1940) (discussed infra in Part III.A.1).

14. Mason v. Paradise Irrigation Dist., 326 U.S. 536, 538 (1946) (discussed infra in Part III.A.2).

15. Oral Opinion on the Record of Judge Rhodes at 30, In re City of Detroit Bankr., No. 13-53846 (Bankr. E.D. MI. Nov. 7, 2014), available at http://www.mieb.uscourts.gov/ sites/default/files/notices/Oral_Opinion_on_Detroit_Plan_Confirmation_Judge_Rhodes_FI NAL_for_Release.pdf.

16. $\overrightarrow{I d}$. 
This article contends that the court's analysis can be - and should be viewed through the analytical framework that was developed by Professor Bruce Markell and adopted by many courts in corporate reorganization cases. $^{17}$ That framework, the Markell Test, permits discrimination to the extent it comports with the parties' ex ante expectations or compensates the favored party for contributions to the reorganization. ${ }^{18}$ This latter factor is at times referred to as the "new value corollary."19 The Markell Test considers many of the same factors that informed the Detroit court's judgment. Furthermore, this article contends that the new value corollary, properly interpreted, more effectively addresses the court's mission-related concerns.

The article begins with a description of Chapter 9's structure and policies. Chapter 9 is a pared-down form of Chapter 11's corporation reorganization law, including many of the Chapter 11 procedures for negotiating and confirming a debt composition plan. But, Chapter 9 intentionally excludes most of Chapter 11 's creditor protections, as Congress has attempted to carefully craft Chapter 9 to minimize federal intrusion into municipal governance. Thus, while Chapter 11 serves the dual (and sometimes inconsistent) purposes of promoting reorganization and of maximizing returns to creditors, Chapter 9's purpose is solely to confirm a debt composition plan.

Part II focuses on the unfair discrimination rule's function within the limited structure and scope of Chapter 9. This rule limits how the municipal debtor may allocate its reorganization value among similarly situated classes of creditors. Although this rule has not played a significant role in corporate reorganizations, it is likely to do so in municipal bankruptcies, especially to the extent municipal debtors seek to impair their pension obligations under Chapter 9.

Part III then analyzes the meaning of the unfair discrimination rule, first looking at its historical meaning under Chapter IX of the Bankruptcy Act of 1898. Then, consistent with that historical use and with Chapter 9's incorporation of the unfair discrimination rule from Chapter 11, this part will then examine the Chapter 11 case law interpreting the unfair discrimination rule.

Part IV then discusses how these rules should be interpreted in the Chapter 9 context. This part argues that the unfair discrimination rule should be interpreted the same in Chapter 9 as in Chapter 11; however, the new value corollary within the unfair discrimination rule should be applied

17. Bruce A. Markell, A New Perspective on Unfair Discrimination in Chapter 11, 72 AM. BANKR. L.J. 227 (1998) (discussed in detail infra Part III.B.2).

18. Id. at 242.

19. David R. Kuney, 8 J. Bankr. L. \& Prac. 505, 505 n.3 (1999) 
more flexibly in municipal bankruptcies. While there is some policy support for a narrow interpretation of new value in Chapter 11, consistent with that chapter's structure and policy, the structure and policies of Chapter 9 require a more flexible approach in municipal bankruptcies. This approach would provide a more predictable and useful tool in analyzing unfair discrimination issues, as it would provide a structure for determining not just whether discrimination is fair but also how much discrimination is fair. It would further provide a better framework for dealing with the challenging question of the relative treatment of tort and other involuntary creditors.

\section{CHAPTER 9'S STRUCTURE AND POLICY}

Municipal bankruptcy law shares key features of corporate reorganization law. ${ }^{20}$ For this article, the key similarity is that both Chapters 9 and 11 are constructed around the confirmation of a debt composition plan, which confirmation carries with it the "extraordinary power" to bind even dissenting creditors. ${ }^{21}$ At the same time, though, there are important and significant differences between Chapter 9 and Chapter 11. This section describes the similarities and key differences between the two chapters of the Bankruptcy Code, and it argues that these differences reflect the different policies underlying these chapters. ${ }^{22}$

The main similarity between municipal and corporate bankruptcy law is the centerpiece of a debt composition plan. Chapter 9 directly incorporates many of Chapter 11's plan-related provisions - for instance, it incorporates the rules relating to the classification of claims ${ }^{23}$, acceptance

20. See Juliet M. Moringiello, Goals and Governance in Municipal Bankruptcy, 71 WASH. \& LEE L. REv, 403, 410 (2014) (highlighting that authors have compared municipal bankruptcy law to corporate bankruptcy, striking similarities between Chapter 9 and Chapter 11); Omer Kimhi, Chapter 9 of the Bankruptcy Code: A Solution in Search of a Problem, 27 YALE J. ON REG. 351, 356 (2010) (describing municipal bankruptcy law as "corporate bankruptcy mutatis mutandis").

21. See Pryor, supra note 9, at 114 ("The extraordinary power of plan confirmation lies in its power to bind non-consenting members of a class when the class votes in favor of the plan."). As discussed infra, this is handled in two ways. First, creditor voting is by class, such that a class as a whole may approve the plan over the objections of a minority of the class members. Second, even if a class of creditors opposes the plan, the court may nonetheless impose the plan over that objection if the requirements of Section 1129(b) are satisfied.

22. Moringiello, supra note 20 , at 410 ("Constitutional concerns, coupled with municipal bankruptcy's original limited goal of solving the holdout problem, explain the somewhat skeletal nature of Chapter 9.").

23. 11 U.S.C. $\$ 1122(1978)$. 
of the plan by class, ${ }^{24}$ and most of the plan confirmation requirements. ${ }^{25}$ In other aspects, Chapter 9 draws from Chapter 11 with slight variations. For example, under Chapter 11 , the debtor has the exclusive right to propose a plan during the first 120 days of the case, after which creditors can propose a plan, ${ }^{26}$ while under Chapter 9 only the debtor has the right to propose a plan. ${ }^{27}$

At the same time, though, Chapter 9 significantly departs from other aspects of Chapter 11's plan negotiation process in two primary ways. First, Chapter 9 does not include Chapter 11 's statutory priority structure; second, Chapter 9 does not include many of Chapter 11 's creditor protections. These protections give creditors governance rights in corporate reorganization, i.e., which give creditors the ability to participate in corporate decision making within the bankruptcy context. ${ }^{28}$ Each of these will be discussed in turn in the following sections.

\section{A. Statutory Priority Schemes}

Chapter 11 imposes a statutory priority structure that accords distribution priority to special claimants, such as administrative expenses, employee wage claims, and certain unpaid taxes. ${ }^{29}$ Thus, a plan under Chapter 11 must pay priority creditors in full before distributing any value to the general unsecured creditors. For example, a corporate debtor must pay employees' back wages (up to the statutory limit ${ }^{30}$ ) before paying general unsecured obligations to trade creditors.

Chapter 9 , in contrast, prioritizes only administrative expense claims. ${ }^{31}$ There are no other priority unsecured claims in the municipal bankruptcy context, such that there is no requirement that employees' unpaid wages be paid ahead of other general unsecured creditors - all unsecured claims incurred before the bankruptcy petition share equal priority. ${ }^{32}$

The legislative history is silent as to why Chapter 9 does not include

24. 11 U.S.C. $\$ 1126(1984)$. (2010).

25. 11 U.S.C. $\S \S 1129(a)(2),(a)(3),(a)(6),(a)(8),(a)(10),(b)(1),(b)(2)(A),(b)(2)(B)$

26. 11 U.S.C. $\S 1121$ (b) (2005)

27. 11 U.S.C. $\S 941$ (1978).

28. See Moringiello, supra note 20 , at 456 (detailing Congress' merging of standard bankruptcy law with features of corporate bankruptcy).

29. 11 U.S.C. $\S 507(a)(2),(a)(4)$, and (a)(8) (2010), respectively.

30. Currently, that amount is $\$ 12,475$ for unpaid wages earned in the six months prior to the bankruptcy petition. 11 U.S.C. $\$ 507(a)(4)(2010)$.

31. 11 U.S.C. $\$ 901$ (2010) (incorporating only Section 507(a)(2) from the creditor priorities section).

32. Pryor, supra note 9, at 120 (arguing that the lack of statutory priorities means that all unsecured creditors should be treated equally). 
these statutory priorities. Perhaps it reflects a policy decision to make Chapter 9 "plain vanilla" in order to ensure that it is as useful to as many states as possible - that is, Congress may have been reluctant to impose statutory priorities out of fear that these priorities might make Chapter 9 either unattractive or simply unworkable in some states. Hynes and Walt argue, for instance, that a uniform federal priority for pensioners might not be workable given that "[s]tates can differ with respect to their central and local fiscal conditions, as well as in the extent to which they regulate pension obligations incurred by their municipalities." ${ }^{33}$ A federal rule of priority might even deter states from using Chapter 9, as it would "force some states to allocate the direct and indirect costs of a municipal bankruptcy in a way they would not prefer." 34

Perhaps Congress intended for states to prioritize their own debts. ${ }^{35}$ While under modern bankruptcy law, state law priorities do not apply in bankruptcy unless the Bankruptcy Code specifically incorporates them, this was not the case when Congress enacted the first municipal bankruptcy law. ${ }^{36}$ Prior to the Chandler Act of 1938, bankruptcy law incorporated state law creditor priorities. ${ }^{37}$ Thus, when Congress enacted the first municipal bankruptcy laws in 1934 and 1937, federal bankruptcy law honored statecreated priorities. When Congress eliminated state law priorities from the bankruptcy laws in the Chandler Act, Congress simply never amended the municipal bankruptcy laws to address this change. Thus, perhaps the continued lack of statutory priorities is simply an accident of history.

Finally, it may be that Congress deliberately refused to impose statutory priorities out of federalism concerns, as any distributional requirements would impose federal policies on the state. ${ }^{38}$ This explanation

33. Hynes \& Walt, Pensions \& Property Rights, supra note 9, at 660.

34. Id.

35. See Adam J. Levitin, Detroit Eligibility and Pensions, CreditSliPs, (Dec. 3, 2013, 8:45 PM), http://www.creditslips.org/creditslips/2013/12/detroit-eligibility-and pensions.html (suggesting that the municipal bankruptcy laws leave room for state priorities and arguing for the implicit use of states prioritizing their own debts).

36. See David Skeel, What is a Lien? Lessons from Municipal Bankruptcy 9 (Univ. of Penn. Law Sch. Faculty Scholarship Paper No. 1387, 2014), available at http://scholarship.law.upenn.edu/cgi/viewcontent.cgi?article=2388\&context=faculty_scholar ship ("As originally enacted, the 1898 Act incorporated any nonbankruptcy priorities that were honored under state or federal law. Concerned that there was little or nothing left for general unsecured creditors in most cases after state law priorities were satisfied, lawmakers largely eliminated state law priorities under the Chandler Act of 1938, which made major changes to the 1898 Act.").

37. Id.

38. See, e.g., Lynn Hume, Bill Would Give More Rights to Municipal Employees in Bankruptcies, SOURCEMEDIA (June 4, 2014), http://www.bondbuyer.com/news/washingtonbudget-finance/bill-would-give-more-rights-to-municipal-employees-in-bankruptcies1063100-1.html (raising the federalism concern of states being governed by federal rules). 
seems entirely consistent with Congress's continued care to ensure that municipal bankruptcy law does not overstep into local municipal governance.

Whatever the reason or justification, Congress has opted to not impose a federal priority scheme on municipal debtors in Chapter 9 , a decision in line with its decision to leave debtors in control of municipal governance.

\section{B. Governance Mechanisms}

Governance-wise, Chapter 11 empowers creditors to participate in corporate decision making in ways not allowed in Chapter 9.9 ${ }^{39}$ For instance, corporate creditors have the right to be heard relating to any nonordinary course business decisions the debtor may want to pursue ${ }^{40}$; may move to have a trustee appointed to displace management ${ }^{41}$; and may propose their own plan of reorganization if the debtor fails to propose one or fails to propose one that garners sufficient creditor support. ${ }^{42}$ None of these governance provisions are applicable in Chapter 9. In fact, Chapter 9 specifically prohibits any interference with municipal governance. Section 903 acknowledges that a state retains the power "to control, by legislation or otherwise, a municipality of or in such State in the exercise of the political or governmental powers of such municipality, including expenditures for such exercise.",43 Section 904 further prohibits court interference with municipal governance:

Notwithstanding any power of the court, unless the debtor consents or the plan so provides, the court may not, by any stay, order or decree, in the case or otherwise, interfere with -

Any of the political or governmental powers of the debtor;

Any of the property or revenues of the debtor; or

The debtor's use or enjoyment of any income-producing property. ${ }^{44}$

39. Some, in fact, have characterized corporate bankruptcy as a component of corporate governance generally. See, e.g., George G. Triantis, The Careful Use of Comparative Law Data: The Case of Corporate Insolvency Systems, 17 N.Y.L. SCH. J. INT'L \& CoMP. L. 193, 195 ("Most recently, a theory of insolvency law is evolving that views bankruptcy as a corporate governance mechanism. Perhaps because my interest in bankruptcy has evolved from earlier research into patterns of debt financing, I have subscribed to a governance view of bankruptcy.").

40. 11 U.S.C. $\$ 363(b)(1)(2010)$.

41. 11 U.S.C. \$ $1104(2010)$.

42. 11 U.S.C. $\$ 1121$ (c) (2005).

43. 11 U.S.C. $\$ 903$ (1984).

44. 11 U.S.C. $\S 904$ (1978). 
While there has been some debate about whether municipal bankruptcy law should impose more governance restrictions, it clearly does not do so now. ${ }^{45}$ As Juliet Moringiello explains, Chapter 9's focus on debt adjustment - and exclusion of reorganization governance - reflects both constitutional concerns as well as "municipal bankruptcy's original limited goal of solving the holdout problem." 46

When Congress created the first municipal bankruptcy law in 1934, it did so with the narrow purpose of providing a means for municipalities to re-negotiate their bond debts. ${ }^{47}$ At the time, under the then-current Contracts Clause jurisprudence, it was understood that any state law procedure to re-negotiate bond debt requires unanimous bondholder consent, as imposing terms on a dissenting holdout bondholder would be an unconstitutional impairment of contract. ${ }^{48}$ Thus, municipal bankruptcy law under Chapter IX was structured to address this one problem, and this one problem alone.

The singular focus of Chapter IX was evident in its structure. A municipal debtor could obtain bankruptcy relief only after negotiating a plan of debt composition that had been approved by a majority of its creditors. ${ }^{49}$ This entry-level requirement made it practically impossible for

45. See, e.g., Michael W. McConnell \& Randal C. Picker, When Cities Go Broke: A Conceptual Introduction to Municipal Bankruptcy, 60 U. CHI. L. Rev. 425, 494 (1993) ("We believe that federal bankruptcy law warrants serious reexamination. In its present form, it serves little use: it does little to address serious city problems and, by restricting state laws directed at solving the holdout problem, even impedes the ability of states to institute superior schemes for dealing with cities that have gone broke.").

46. Moringiello, supra note 20 , at 410.

47. See Kimhi supra note 20, at 365 (explaining that Chapter IX's primary purpose was overcoming the holdout problem).

48. See United States v. Bekins, 304 U.S. 27, 54 (1938) (describing the Contracts Clause and the constitutionality of municipal bankruptcy law stating "the natural and reasonable remedy through composition of the debts of the district was not available under state law by reason of the restriction imposed by the Federal Constitution upon the impairment of contracts by state legislation.") and Ashton v. Cameron County Water Improvement Dist. No. 1., 298 U.S. 513, 531 (1936) ("The Constitution was careful to provide that 'no State shall . . . pass any ... Law impairing the Obligation of Contracts.' This she may not do under the form of a bankruptcy act or otherwise. Nor do we think she can accomplish the same end by granting any permission necessary to enable Congress so to do.") (internal citations omitted). But see Whitney Cloud, Comment, State Pension Deficits, the Recession, and A Modern View of the Contracts Clause, 120 YALE L. J. 2199 (2011) (arguing that the recent financial crisis provides a justification for impairing public employment contracts).

49. See Revised Municipal Bankruptcy Act, Pub. L. No. 302, § 83(a), 50 Stat. 653, 655 (1937) ("The petition shall state that a plan of composition has been prepared, is filed and submitted with the petition, and that creditors of the petitioner owning not less than 51 per centum in amount of the securities affected by the plan ... have accepted it in writing."). 
a debtor to use bankruptcy for any broader purpose than to adjust a single type of indebtedness. ${ }^{50}$

Despite the limited focus of the original Chapter IX, the Supreme Court found it to be unconstitutional as it threatened to interfere with local fiscal affairs, thus exceeding the scope of Congress's constitutional powers. ${ }^{51}$ The Court reversed course two years in upholding a (slightly) revised municipal bankruptcy law, holding that, to the extent the federal law encroaches on municipal fiscal affairs, it does so only at the request of the states themselves. ${ }^{52}$

Following the Revised Municipal Bankruptcy Act of 1937, Congress expanded the powers available to a debtor under Chapter IX and eased the entry requirement by getting rid of the requirement that the municipality have a pre-approved plan. ${ }^{53}$ But even in doing so, Chapter 9 remained focused on debt adjustment and carefully circumscribed the law to prevent federal intrusion into municipal governance. ${ }^{54}$ The legislative history to the 1976 revisions to Chapter IX explains that the changes did not expand the scope of the law:

Chapter IX provides essentially for Federal court supervision of a settlement between the petitioner municipality and a majority of its creditors. A municipal unit cannot liquidate its assets to satisfy its creditors totally and finally. Therefore, the primary purpose of a Chapter IX is to allow the municipal unit to continue operating while it adjusts or refinances creditor claims with minimum (and in many cases, no) loss to its creditors. ${ }^{55}$

Two years later when Congress overhauled the bankruptcy laws with

50. Such pre-approved (or "pre-packaged" filings) are permitted under Chapter 11 of the Bankruptcy Code, and as commenters have noted, such pre-packaged filings almost necessarily handle just one layer of the capital structure. See Marc S. Kirschner, Dan A. Kusnetz Laurence Y. Solarsh, Craig S. Gatarz, Prepackaged Bankruptcy Plans: The Deleveraging Tool of the '90s in the Wake of OID and Tax Concerns, 21 SETON HALL L. REv. 643, 661 (1991) ("As a practical matter, the pre-packaged bankruptcy unfolds in a manner similar to an out-of-court exchange offer: there is a negotiation with major bondholders, the preparation of offering literature (a combination exchange offer and disclosure statement) and the negotiation of a plan.").

51. Ashton v. Cameron Cnty. Water Improvement Dist. No. 1, 298 U.S. 513, 532 (1936).

52. Bekins, 304 U.S. at 27.

53. Pub. L. No. 94-260, 90 Stat. 315 (1976). Following New York City's financial crisis in the early 1970s, Congress expanded Chapter IX in order to make it more workable for large cities.

54. Moringiello, supra note 20 , at 455 .

55. H. R. REP. No. 94-686, at 6 (1975). 
the Bankruptcy Reform Act of 1978, Congress created Chapter 9 of the Bankruptcy Code with only technical changes to the old Chapter 9. ${ }^{56}$ Chapter 9 incorporates many of its provisions from Chapter 11, the new corporate reorganization chapter, thus linking the two chapters together. ${ }^{57}$

Because a significant portion of Chapter 9 includes provisions incorporated from Chapter 11, some have argued that Congress intended municipal bankruptcy to be more or less similar to corporate reorganizations. ${ }^{58}$ Omer Kimhi has described Chapter 9 as "a corporate bankruptcy procedure mutatis mutandis. $" 59$

The legislative history, though, clearly reflects an understanding that, despite their procedural similarities, Chapter 9 is significantly different in scope and purpose than Chapter 11:

The general policy underlying the municipal debt adjustments chapter is the same as that underlying the [business] reorganization chapter. The Chapter gives the debtor a breathing spell from debt collection efforts in order that it can work out a repayment plan with its creditors. There are two major differences from general reorganization law: first, the law must be sensitive to the issue of the sovereignty of the States; second, a municipality is generally not a business enterprise operating for profit, and there are no stockholders. These differences dictate some limitations on the court's powers in dealing with a municipal debt adjustment, and some modifications of the standards governing the proposal and confirmation of a plan. ${ }^{60}$

The narrow scope of Chapter 9 - with its focus on confirming a debt readjustment plan - and its conscious effort to limit federal intrusion in to municipal governance reflect these concerns about state sovereignty. They also reflect the narrower policy of Chapter 9. Whereas Chapter 11 serves the dual, and at times conflicting, policies of maximizing returns to creditors and facilitating the debtor's reorganization, ${ }^{61}$ the legislative history emphasizes that "the primary purpose of Chapter 9 is to allow the municipal unit to continue operating while it adjusts or refinances creditor

56. Kimhi, supra note 20 , at 368-69.

57. Id.

58. Id. at 369 ("Indeed, Congress's underlying assumption was that the two chapters are more or less the same.").

59. Id.

60. H.R. REP. NO. 95-595, at 263 (1977).

61. See Michelle M. Harner, The Search for an Unbiased Fiduciary in Corporate Reorganizations, 86 Notre DAME L. REV. 469, 476 (2011) (rehabilitating corporate debtors and maximizing recoveries to creditors are the primary goals of Chapter 11). 
claims with minimum (and in many cases, no) loss to its creditors."

\section{FUNCTION OF THE UNFAIR DisCRIMINATION RULE}

The unfair discrimination rule is an element of the "cram down" requirements that must be met before a court can confirm a non-consensual debt adjustment plan. These requirements are found in Section 1129(b) of the Bankruptcy Code and are, thus, applicable in Chapter 11 cases. Section 901 makes these requirements applicable in municipal bankruptcy as well. These requirements state that, in order for a court to confirm a debt adjustment plan over the objection of a class of creditors, the court must find that "the plan does not discriminate unfairly, and is fair and equitable, with respect to each class of claims or interests that is impaired under, and has not accepted, the plan." ${ }^{.63}$

While these rules apply only in the event that there is a dissenting class of creditors, they shape the plan negotiation process by providing a background set of rules applicable in the event the debtor cannot achieve consensual support for its plan. As Kenneth Klee, one of the drafters of the Bankruptcy Code, explained shortly after the new law was enacted, even though the cram down rules apply only if a class dissents, "one of the hypotheses of the Code is that the rule will also affect the negotiating posture of the debtors and creditors with respect to formulation of a plan.",64 Melissa Jacoby has made this point specifically about the Detroit plan confirmation process, explaining that " $[t]$ he strength of the cramdownrelated arguments contribute to the leverage of the parties to compromise and settle. ${ }^{.65}$

These requirements impose a limit on a debtor's freedom in allocating value under a debt adjustment plan. ${ }^{66}$ In both Chapters 9 and 11, the Bankruptcy Code provides a baseline distributional requirement that the plan be in the best interests of creditors. ${ }^{67}$ In Chapter 11, this means that the creditors must receive as much under the plan as they would have received under a Chapter 7 liquidation. $^{68}$ In Chapter 9 , it has been

62. H.R. REP. NO. 95-595, at 263.

63. 11 U.S.C. $\S 1129(\mathrm{~b})(1)(2010)$.

64. Kenneth N. Klee, All You Ever Wanted to Know About Cram Down Under the New Bankruptcy Code, 53 AM. BANKR. L.J. 133, 134 (1979).

65. Melissa Jacoby, $Q \& A$ on $C$ of $D$, Credit Surs (June 6, 2014), http://www.creditslips.org/creditslips/2014/06/q-a-on-c-of-d.html.

66. See Pryor, supra note 9, at 85-86 (noting that the "fair and equitable" and unfair discrimination rule limit the plan's freedom in allocating risk).

67. Id. (identifying the best interests requirement as a third limitation on risk allocation).

68. 11 U.S.C. $\S 1129(\mathrm{a})(7)(2010)$. 
suggested that this requirement means that creditors must receive at least as much as they would have received under state collection laws, generally under a mandamus action. ${ }^{69}$ A debtor has freedom to allocate any value above this baseline - the "reorganization surplus" - but that freedom is constrained by the creditors' right to oppose the debtor's plan. The court may confirm a plan over the objections of dissenting creditors only if it finds that the plan is (1) fair and equitable and (2) does not discriminate unfairly as to those dissenting creditors.

These two rules - the unfair discrimination rule and the fair and equitable rule - thus enable a court to confirm a plan even over the objection of a class of creditors but only if the court finds that their interests were protected. As discussed in the following section, these two rules were conflated at one point, but they have developed into two freestanding tests.

\section{A. Development of Unfair Discrimination Rule}

Historically, the fair and equitable rule and the unfair discrimination rule were conflated, with the fair and equitable rule serving as a broad set of principles that included that of unfair discrimination. ${ }^{70}$ Both rules derived from principles developed in the equity receivership cases of the 1900 s. $^{71}$ During that time, there was no reorganization procedure for corporations. Instead, corporate debtors sought to reorganize through an equity receivership. Under this receivership procedure, a corporation or railroad attempting to reorganize its debts could do so through a voluntary workout or, barring that, through a legal device called an equity receivership. ${ }^{72}$ An unsecured creditor could petition a court to appoint a receiver to take control of the railroad's assets. At the foreclosure sale, a committee of old creditors would then "purchase" the railroad through a credit bid - that is, not by contributing new cash but by bidding with the face value of their notes. As Stephen Lubben notes, "[o]ne of the most controversial features of receiverships was the frequency with which

69. See 6 COLLIER ON BANKRUPTCY I 943.03 (Alan N. Resnick \& Henry J. Sommers eds., 16th ed.) ("The concept should be interpreted to mean that the plan must be better than the alternative that creditors have. In the chapter 9 context, the alternative is dismissal of the case, permitting every creditor to fend for itself in the race to obtain the mandamus remedy and to collect the proceeds.").

70. See Markell, supra note 17, at 232-33 (1998) (discussing how Congress, courts, and commentators treated the fair and equitable rule as including the unfair discrimination rule).

71. Id. at 228-31.

72. Stephen J. Lubben, Railroad Receiverships and Modern Bankruptcy Theory, 89 CORNELL L. REv. 1420, 1445 (2004). 
existing shareholders were able to maintain their position in the reorganized railroad, despite the failure to pay creditors in full." ${ }^{, 73}$

In response to these concerns, the equity receivership courts created equitable protections for these unsecured creditors who got squeezed out between the secured creditors and the old shareholders, which protections were broadly cabined under the requirement that the plan be "fair and equitable." ${ }^{, 74}$ Courts would variously refer to these protections as embodying basic principles of debt compositions that shareholders could not be paid before dissenting creditors and that creditors should be treated equally. ${ }^{75}$

When drafting the first municipal, corporate, and railroad bankruptcy provisions in the 1930s, Congress required that the debt composition plan be approved by creditors and that the court be satisfied that the plan "is fair, equitable, and for the best interests of the creditors, and does not discriminate unfairly in favor of any class of creditors". ${ }^{76}$

Congress revised the business bankruptcy provisions shortly thereafter in the Chandler Act and removed the unfair discrimination language, leaving only the requirement that the plan be "fair and equitable." "77 The

73. Id.

74. John D. Ayer, Rethinking Absolute Priority After Ahlers, 87 Mich. L. REv. 963, 972 (1989) (characterizing that decision as prohibiting the "old bondholders and stockholders" from "'squeezing out' the intermediate unsecured debt").

75. See, e.g., Case v. Los Angeles Lumber Prods. Co., 308 U.S. 106 (1939) (commenting on the discrepancy between shareholders and creditors suggesting that equality should be attained) and Northern Pacific Railway Co. v. Boyd, 228 U.S. 482 (1913) (same); see also Bruce Markell, Owners, Auctions, and Absolute Priority in Bankruptcy Reorganizations, 44 STAN. L. REv. 69, 78-90 (1991) (exploring the relationship between the absolute priority rule and new value principles by examining the historical origins).

76. Pub. L. No. 251, § 80(e), 48 Stat. 798, 801 (1934). The Supreme Court found this law to be unconstitutional in 1936, after which Congress passed a Revised Municipal Bankruptcy Act in 1937, Pub. L. No. 302, 50 Stat. 653 (1937), which was nearly identical. It kept the unfair discrimination rule, stating that the court shall confirm the plan "if satisfied that (1) it is fair, equitable and for the best interests of the creditors and does not discriminate unfairly in favor of any creditor or class of creditors." $\S 83(\mathrm{e}), 50$ Stat. at 658 (emphasis added to highlight the changed language). The railroad amendments required the judge to find that the plan "is fair, equitable, and for the best interests of the creditors, and does not discriminate unfairly in favor of any class of creditors." Pub. L. No. 74-381, $\S$ 77(e), 49 Stat. 911, 918 (1935). The corporate amendments required the judge to find that the plan "(1) it is fair and equitable and does not discriminate unfairly in favor of any class of creditors or stockholders, and is feasible." Pub. L. No. 73-296, § 77B(f), 48 Stat. 911,919 (1934)

77. The Bankruptcy Act of 1938, commonly known as the Chandler Act, required that the plan be "fair and equitable." Pub. L. No. 75-696, § 221, 52 Stat. 840, 897 (1938); see Markell, supra at note 17, at 232. ("Each of these revisions omitted the prohibition of unfair discrimination, inserting in its place a requirement that 'the plan [be] fair and equitable, and feasible."”). 
legislative history explains that Congress did not intend to remove the unfair discrimination protection; rather, Congress viewed this protection as inherent within the broader "fair and equitable" requirement, thus making redundant to include the unfair discrimination language. ${ }^{78}$

Congress subsequently removed the "fair and equitable" language altogether from business bankruptcies under Chapter XI (which applied to smaller businesses, at least in theory) ${ }^{79}$ The justification for this removal was that these creditor protections were not needed in these smaller business bankruptcies.

Both the fair and equitable rule and unfair discrimination rules, however, remained in the municipal bankruptcy laws under Chapter IX. As discussed infra in Part III.A, the Supreme Court recognized that the unfair discrimination rule was a subset of the broader fair and equitable principles developed in those old equity receivership cases and early bankruptcy cases.

When Congress overhauled the bankruptcy laws in the Bankruptcy Reform Act of 1978, it re-introduced both the unfair discrimination and fair and equitable rules in the cram down procedures for Chapters 9 and $11{ }^{80} \mathrm{It}$ did so directly in Chapter 11 in Section 1129(b), and it amended Chapter 9 to incorporate the Chapter 11 requirements.

\section{B. Vertical vs. Horizontal Protections}

The legislative history clearly contemplates these two rules as serving different functions, although the history is not very helpful in interpreting the exact parameter of these functions. ${ }^{81}$ Bruce Markell, in one of the most influential articles on the unfair discrimination rule, has characterized these functions as providing both vertical and horizontal limits on a debtor's freedom to allocate the reorganization surplus:

Just as the fair and equitable requirement regulates priority among classes of creditors having higher and lower priorities, creating inter-priority fairness, so the unfair discrimination provision promotes intra-priority fairness, assuring equitable

78. S. REP. No. 75-1916, at 35-36 (1938) (Senate Report No. 1916 accompanied H.R. 8046 , which was the bill ultimately enacted) ("a prohibition against any unfair discrimination in the plan in favor of any creditors or stock-holders and the express statement to that effect in Section 77B is therefore unnecessary.").

79. KenNETH N. KLEe, BANKRUPTCY AND THE SUPREME COURT 390 n.2083 (2009).

80. Pub. L. No. 95-598, 92 Stat. 2549 (1978).

81. H.R. REP. No. 95-595, at 416-17 (1977), reprinted in 1978 U.S.C.C.A.N. 5963, 6373. 
treatment among creditors who have the same level of priority. ${ }^{82}$

Although the absolute priority rule and the unfair discrimination rule impose different types of limitation, they both serve the same function of placing a limit on how a plan can allocate value among classes of creditors. These limitations can only be invoked by a dissenting class of creditors thus, there must be such a dissenting class; however, they cast a shadow over the plan negotiation process. ${ }^{83}$ These rules create the legal backdrop against which plan negotiations take place, thus shaping the parties' negotiation positions even prior to a vote on the plan.

Most case law and scholarship has focused on the vertical limits of the fair and equitable rule, as a frequent issue is whether a debtor should be able to allocate value to old stockholders even when it has not paid its creditors in full. ${ }^{84}$ Congress clarified that the fair and equitable rule includes the so-called absolute priority rule, which requires that dissenting senior claimants be paid in full before the plan distributes any value to junior claimants. ${ }^{85}$ The cases and scholarship on this rule - while diverging on how it should be applied - all recognize that it functions to limit a debtor's freedom to allocate the reorganization surplus, i.e., the value in excess of the debtor's liquidation value. ${ }^{86}$

Whereas the fair and equitable rule's vertical limitation plays a significant role in shaping plan negotiations in the Chapter 11 context, it is less likely to do so in the Chapter 9 context. $^{87}$ There are no shareholders in this context, and so the traditional fight between the creditors and the shareholders is simply not present. This is not to say that the fair and equitable rule has no meaning in this context, as that rule is broader than just the absolute priority rule. ${ }^{88}$ But the lack of shareholders eliminates a

82. Markell, supra at note 17 , at 228 .

83. Klee, supra note 64 and accompanying text; Jacoby, supra note 65 and accompanying text.

84. Hynes \& Walt, Pensions \& Property Rights, supra note 9 at 630 ("Most prior writing on municipal bankruptcy has focused on the test of vertical equity.").

85. 11 U.S.C. $\$ 1129(b)(2)$.

86. See Douglas G. Baird, Bankruptcy's Uncontested Axioms, 108 YALE L.J. 573, 585 (1998) (explaining that the only debatable issue relates to adding new value to the company to overcome the creditors' objections).

87. See Omer Kimhi, Reviving Cities: Legal Remedies to Municipal Financial Distress, 88 Boston UnIV. L. REV. 633, 652 (2008) (considering the limited applicability of the absolute priority rule in protecting the interests of unsecured creditors).

88. See Pamela Foohey, Chapter 11 Reorganization and the Fair and Equitable Standard: How the Absolute Priority Rule Applies to All Nonprofit Entities, 86 ST. JOHN's L. REv. 31, 33 (2012) (discussing the application of the fair and equitable rule in the context of non-profit corporations which likewise have no shareholders: "Simply because Chapter 11 does not contemplate nonprofits' unique structures and operational goals does not mean that 
common source of disputes under the fair and equitable rule. Further, the fair and equitable rule's vertical protection is generally less applicable as municipal bankruptcy has less "verticality" to protect, as the priority structure is flatter in the municipal context, as there are no statutory priorities.

In this flatter priority structure, the unfair discrimination role is likely to play a significant role in limiting the debtor's ability to allocate the reorganization surplus in Chapter 9. This is particularly so if municipal debtors seek to use bankruptcy to impair pensions obligations, as has happened in Detroit and Stockton, California. This is so because, even though their claims arise from different sources, pension and bond claims occupy the same priority level. Accordingly, the unfair discrimination rule will shape a municipal debtor's negotiations in crafting a plan that will allocate more (or less) value to pensioners relative to bondholders and other unsecured creditors. $^{89}$

A brief description of Detroit's plan of adjustment here serves to illustrate the unfair discrimination rule's impact in a municipal bankruptcy plan that proposes to impair public pensions.

\section{Detroit}

This section will describe Detroit's negotiations with its unsecured creditors, principally its pension claimants and bondholders. The negotiations and ultimate resolution highlight the role of the unfair discrimination rule. As both pensioners and bondholders have claims of the same legal status, the unfair discrimination rule provided the legal framework for negotiations among these claimants, as the rule would apply if any class voted against the plan.

The cornerstone of these negotiations is a settlement that combines the two most controversial aspects of the case: the treatment of pensioners and the treatment of Detroit's world-class art collection at the Detroit Institute of Arts (DIA). This settlement has been called the Grand Bargain. ${ }^{90}$

The Grand Bargain is a multiparty settlement involving the state of

the guiding policies behind the requirements of Chapter 11 should not apply with the same force and intention to nonprofits. In an effort to bring courts one step closer to applying the same rigorous approval criteria to nonprofits' reorganization plans, this Article focuses on one crucial aspect of courts' evaluation of plans - the fair and equitable standard.").

89. See Skeel, supra note 9 , at 19 (noting that the unfair discrimination rule "may prove extremely important in a case like Detroit - much more important than commentators have recognized thus far.").

90. David A. Skeel, From Chrysler and General Motors to Detroit 15 (Univ. of Penn. Law Sch. Faculty Scholarship Paper No. 1420, 2014), available at http://scholarship.law.upenn.edu/faculty_scholarship/1420. 
Michigan, a consortium of private institutions, the DIA, and Detroit's pensioners. It contemplates four major moves: (1) the City will transfer the DIA assets to a public trust that will keep the artwork in Detroit in perpetuity ${ }^{91}$ (2) the DIA and private institutions (such as the Kellogg Foundation, the Ford Foundation, General Motors, the United Autoworkers) will contribute no less than $\$ 466$ million over 20 years to fund the pensions, ${ }^{92}$ (3) the state of Michigan will likewise contribute the net present value of $\$ 350$ million over 20 years to fund the pensions ${ }^{93}$; and (4) the pensioners will drop their objections and appeals and support the plan. ${ }^{94}$

The foundations and the DIA successfully raised the requisite funds; the Michigan legislature approved a bill that will send a one-time $\$ 194.8$ million to the pensions; ${ }^{95}$ and the retiree committee endorsed the plan. ${ }^{96}$ The remaining question leading up to Detroit's trial on plan confirmation was whether, if the bondholders opposed the plan, the court would find that the plan unfairly discriminated in favor of the pensioners.

The question, then, was whether this arrangement could be confirmed without the consent of the bondholders, who were cut out of this Grand Bargain. The bondholders argued that the City could get more money from an auction of the DIA assets - enough that might actually fully fund the pensions and pay the bondholders. ${ }^{97}$

Without the consent of the bondholder class of creditors, the plan could be confirmed only under the "cram down" provisions of Section 1129(b), which require the court to find that the plan is fair and equitable and does not unfairly discriminate as to the class of bondholders. ${ }^{98}$

91. Fifth Amended Plan for the Adjustment of Debts of the City of Detroit at $51, \ln$ re City of Detroit Bankr., No. 13-53846 (Bankr. E.D. Mich. July 25, 2014) [hereinafter Fifth Amended Plan] ("Transfer of DIA Assets. On the Effective Date, the City shall irrevocably transfer the DIA Assets to DIA Corp., as trustee, to be held in perpetual charitable trust, and within the City limits, for the primary benefit of the residents of the City and the Counties and the citizens of the State.")

92. Id. This includes $\$ 366$ million from the foundations and an additional $\$ 100$ million from the DIA. The foundations are listed in Exhibit B to the Disclosure Statement.

93. Id.

94. Id. at 50-51.

95. Kathleen Gray, Michigan Senate OKs historic $\$ 195 M$ Detroit aid package; Snyder's signature next, DeTROIT FREE PRESS (June 4, 2014), http://www.freep.com/ article/20140603/NEWS06/306030043/Detroit-bankruptcy-pensions-artwork.

96. Karen Pierog, Detroit Retiree Committee Reaches Deal on Pensions, Healthcare, REUTERS (April 26, 2014), http://www.reuters.com/articie/2014/04/26/usa-detroitbankruptcy-idUSL2N0N101920140426.

97. Steven Church, Detroit Bond Insurer Syncora Calls 75\% Debt Recovery Fair, BLOOMBERG NEws (Sept. 4, 2014), http://www.bloomberg.com/news/2014-09-03/syncoraseeks-75-debt-repayment-in-detroit-restructuring.html.

98. 11 U.S.C. $\S 1129(2010)$. The court must also find that the plan is feasible and in 
Leading up to the confirmation hearing, Detroit reached settlements with the two main bond insurers, increasing the distributions to those insurers in exchange for their support of the plan. Two "catch all" classes of unsecured creditors continued to oppose the plan, however. The first was the "convenience class" - that is, those with small claims - and the second included individual plaintiffs with claims against the city for injuries such as tort and civil rights damages. ${ }^{100}$

\section{THE UNFAIR DISCRIMINATION RULE'S MEANING}

The prior section described the function of the unfair discrimination rule in limiting a municipal debtor's allocation of the reorganization value. It concluded by considering the role of unfair discrimination in the confirmation of Detroit's plan of adjustment. This section will discuss how courts have interpreted this rule.

There has been no case law interpreting this rule under Chapter 9, so this section will begin in Part III.A with a historical analysis of this rule under the prior municipal bankruptcy law under Chapter IX of the Bankruptcy Act of 1898. Although the unfair discrimination rule served a slightly different procedural rule under Chapter IX, the case law under Chapter IX provides some guidance as to the meaning of the unfair discrimination rule.

Part III.B will then discuss the Chapter 11 case law interpreting the unfair discrimination rule. Chapter 9 directly incorporates the unfair discrimination rule from Chapter 11, and as discussed in Part III.A, the rule in both chapters draws from the same historical roots.

\section{A. Chapter IX: Avon Park and Paradise Irrigation}

As discussed above, Chapter IX was originally devised for the narrow purpose of giving municipalities a tool to solve the dissenting creditor holdout problem. ${ }^{101}$ Similar to modern bankruptcy law, the old Chapter IX provided two ways that the debtor could solve this holdout problem. The first was through supermajority voting: the plan could be confirmed with

the best interests of all creditors, neither of which is a foregone conclusion. But the unfair discrimination part is likely to play the largest role both in continued negotiations with the bondholders and in any litigation concerning the plan.

99. Fifth Amended Plan, supra note 91, at 6, If 65 (defining "convenience claim" as consisting of any "other unsecured claim" for $\$ 25,000$ or less).

100. Id. at 18, 224 (defining "Other Unsecured Claim" as a catch all category that includes "Section 1983 claims, Indirect Employee Indemnity Claims and Indirect 36th District Court Claims").

101. Supra Part I.B and text accompanying notes $45 \& 46$. 
the approval of creditors holding two thirds in amount of the claims in each class. ${ }^{102}$ Alternatively, if there was a dissenting class, the debtor could confirm the plan "if provision is made in the plan for the protection of the interests, claims, or liens of such creditors or class of creditors." ${ }^{103}$ So just as in modern bankruptcy law, there was supermajority voting within classes and a cram down procedure applicable when there was a dissenting class.

Whereas the unfair discrimination rule today is part of the cram down rules, under Chapter IX the unfair discrimination rule could be raised even if the plan were accepted by all classes. ${ }^{104}$ As originally enacted in 1934, Chapter IX required that a court find that "the plan is fair, equitable, and for the best interests of the creditors, and does not discriminate unfairly in favor of any class of creditors." 105 After the Supreme Court found this law to be unconstitutional in Ashton ${ }^{106}$, Congress passed a Revised Municipal Bankruptcy Act in 1937, which required that again that the plan be fair and equitable and in the best interests of the creditors, but this time said that the plan "does not discriminate unfairly in favor of any creditor or class of creditors." 107

Thus, whereas the modern unfair discrimination rule serves an interclass protection within each level of priority, the Chapter LX rule also applied intra-class, as it could be raised by the dissenting creditors within any class. The two Supreme Court cases infra discussing the rule under Chapter IX both involve such intra-class disputes.

\section{Avon Park, Florida}

In 1940 the Supreme Court considered whether Avon Park, Florida, had unfairly discriminated against bondholders in its plan of adjustment under Chapter IX. ${ }^{108}$ Avon Park had hired an agent, R.E. Crummer \& Co., to negotiate the plan of adjustment (remember, at that time municipalities had to have a pre-approved plan of adjustment in order to file

102. Bankruptcy Act of 1934, Pub. L. No. 251, § 80(d), 48 Stat. 798, 801 (1934), invalidated by Ashton v. Cameron Cnty. Water Improvement Dist. No. 1, 298 U.S. 513 (1936).

103. Id. $\S 80(\mathrm{~d})$

104. Id. $\S 80(\mathrm{e})$ (requiring the judge to find that the plan satisfies the unfair discrimination and fair and equitable rules, and that it "has been accepted and approved as required by the provisions of subdivision (d) of this chapter.").

105. Id.

106. Supra note 50 and accompanying text.

107. Revised Municipal Bankruptcy Act, Pub. L. No. 302, § 83(e), 50 Stat. 653, 658 (1937) (emphasis added).

108. Am. United Mut. Life Ins. Co. v. City of Avon Park, Fla., 311 U.S. 138, 141 (1940). Chapter IX was the precursor to current Chapter 9 of the Bankruptcy Code. Under Chapter IX, the plan of adjustment was referred to as a "plan of composition." 
bankruptcy). ${ }^{109}$ The City was to pay Crummer for these services by assessing charges against the participating bondholders. ${ }^{110}$ Crummer went about soliciting assents from bondholders but, in order to meet the requisite two-thirds approval, bought claims from dissenting bondholders. "I

The City placed all the bonds in the same class, giving them equal treatment within the class. ${ }^{12}$ The requisite supermajority approved the plan, but one of the dissenting bondholders objected to the plan. The dissenting creditor argued, inter alia, that the plan violated the unfair discrimination rule because Crummer was receiving more under the plan than the other bondholders, as Crummer was to receive payment for its services on top of the class-wide distribution. ${ }^{113}$

The Court agreed that this amounted to unfair discrimination. ${ }^{114}$ It explained that unfair discrimination rule reflects the principle of "equality of treatment of creditors," a rule drawn from "the old $\S 12$." 115 It explained that under that previous law and its antecedents, "a composition would not be confirmed where one creditor was obtaining some special favor or inducement not accorded the others, whether that consideration moved from the debtor or from another." 116 The Court cited early 1900s business cases to support that principle, and then said "[t]hat principle has been imbedded by Congress in Chapter IX by the express provision against unfair discrimination." 17

The Court went on to note that the preferred treatment given to Crummer might be appropriate if the debtor could establish that Crummer's benefit reflected the reasonable value of its services. ${ }^{118}$ The Court appears to be relying on the Case v. Los Angeles Lumber Products, Co. for this principle, citing this case a few sentences later. ${ }^{19}$

Los Angeles Lumber is known as one of the foundational cases establishing the "new value rule" (or "new value corollary"). ${ }^{120}$ Los Angeles

109. Id. at $141-42$.

110. Id. at 141 .

111. Id. at 142. Although the court did not specifically find that this was the purpose of Crummer's claim purchases, it said that, "the inference seems clear that some of them were acquired in order to facilitate consummation of the composition by placing them in friendly hands." Id.

112. Id. at $142-43$.

113. Id. at 143 .

114. Id. at $147-48$.

115. Id. at 147 .

116. Id.

117. Id.

118. Id. at 148 .

119. Id. (citing Case v. Los Angeles Lumber, 308 U.S. 106 (1939)).

120. Michelle Craig, Note, The New Value Exception: A Plea for Modification or Elimination, 11 Bankr. Dev. J. 781, 781 \& n.2 (1995) (citing Los Angeles Lumber and 
Lumber did not involve the unfair discrimination rule; rather it involved the absolute priority rule, as the plan proposed to distribute value to the old stockholders even though creditors would not be repaid in full. ${ }^{121}$ The Court found the plan to be not fair and equitable because it departed from the absolute priority rule. ${ }^{122}$ But the Court said that such a departure may be permitted if in exchange for a new value contribution. ${ }^{123}$

Avon Park suggests that this same "new value" principle would apply in the unfair discrimination context, a suggestion that the Court further explored in Mason v. Paradise Irrigation District, below.

\section{Paradise Irrigation District}

In another case penned by Justice Douglas, the Supreme Court again reviewed a plan of adjustment under Chapter IX to determine if it unfairly discriminated among bondholders within the same class. ${ }^{24}$ In that case, Paradise Irrigation District in California sought to re-negotiate its bonds with the aid of the Reconstruction Finance Corporation. ${ }^{125}$ The RFC lent $\$ 252,500$ to the irrigation district, to be used to redeem its bonds at a roughly $50 \%$ discount. ${ }^{126}$ In exchange, the irrigation district was to issue new 4 per cent bonds to the RFC. ${ }^{127}$

The RFC, applying its loan, then purchased claims representing approximately $92 \%$ of the principal amount of the bond debt, but the remaining $8 \%$ held out. ${ }^{128}$ Paradise was then forced to file for relief under Chapter IX, offering to pay the holdouts the same $50 \%$ value as the assenting bondholders had received from the RFC. ${ }^{129}$ RFC, which had purchased the bonds of the assenting creditors, was thus receiving 4 percent refunding bonds while the holdouts were to receive 50 cents on the dollar. One of the holdouts argued this constituted unfair discrimination.

The Court held that this was not unfair discrimination because the RFC had not "by purchasing bonds in the market acquired merely a

noting that "the United States Supreme Court established the "new value exception" to the absolute priority rule).

121. Case v. Los Angeles Lumber, 308 U.S. 106, 111 (1939).

122. Id. at 119 .

123. Id. at 121 .

124. Mason v. Paradise Irrigation Dist., 326 U.S. 536, 538 (1946).

125. The Reconstruction Finance Corporation was a Depression Era independent government agency created under the 1932 Finance Reconstruction Act in order "to provide emergency financing facilities for financial institutions to aid in financing agriculture, commerce, and industry and for other purposes." H.R. REP. No. 72-243 (1932).

126. Mason, 326 U.S. at 539.

127. Id.

128. Id. at 539-40.

129. Id. 
speculative position in the plan of composition" but "has underwritten the whole refinancing program." ${ }^{\prime 30}$ It had thus provided value to the bankruptcy proceeding, and the Court again cited Case v. Los Angeles Lumber for the proposition that, "[i]t has long been recognized in reorganization law that those who put new money into the distressed enterprise may be given a participation in the reorganization plan reasonably equivalent to their contribution." ${ }^{\prime 31}$ That is, again drawing from business bankruptcy cases, it held that the new value exception applies to unfair discrimination, explaining how, "That rule is based on practical necessities. Without the inducement new money could not be obtained." 132

\section{Analysis: Equitable Principles}

Although there have been significant changes in municipal bankruptcy law since Avon Park and Paradise Irrigation, these cases provide two important points in interpreting and applying the unfair discrimination rule.

The first is that the unfair discrimination rule embodies part of the old equitable principles developed in the early 1900 s to protect creditors. One is that of equality among creditors. The other is that a bankruptcy plan may distribute greater value to those creditors that have contributed new value to the reorganization effort.

The principle of equality among creditors can best be understood as stating the aspiration that equally situated creditors will receive equal treatment. It should not be read as a requirement that a plan provide exactly equal treatment to all similarly situated creditors. ${ }^{133}$ Where Congress intended such a rule, it has explicitly said so. For example, the Bankruptcy Code requires that all creditors placed within the same class receive equal treatment. ${ }^{134}$ In contrast, the unfair discrimination rule presumes that some discrimination is appropriate. As Skeel states, "No unfair discrimination is not the same thing as no discrimination." ${ }^{35}$ The principle of equality among creditors does not elucidate when discrimination crosses the line into unfair discrimination.

The new value principle in these cases may be interpreted either as an exception to the unfair discrimination rule or as a separate factor to be considered under the "fair and equitable" principles. The general premises

130. Id. at 541 .

131. Id. at $541-42$

132. Mason, 326 U.S. at 542 .

133. But see infra note 143 (noting that a few outlier cases have indeed read the unfair discrimination rule so narrowly as to say that any material discrimination is per se unfair).

134. 11 U.S.C. $\S \S 1123(a)(4), 1322(a)(3)$.

135. Skeel, supra note 9, at 19. 
of the rule - that parties which contribute to the reorganization effort should get special treatment - is reflected in various portions of the modern Bankruptcy Code. For example, a court may award statutory administrator priority (thus, effectively guaranteeing payment in full) to those expenses incurred by the bankruptcy that represent "the actual, necessary costs and expenses of preserving the estate". ${ }^{136}$ These may include the professional fees incurred in administering the case. ${ }^{137}$ In fact, if Avon Park or Paradise Irrigation were brought under current law, they most likely would be litigated not under the unfair discrimination rule but on a determination of whether the expenses paid to the favored party reflected the necessary costs of effectuating the plan.

The second broad principle to be derived from these cases is that the unfair discrimination rule in Chapter IX has long been understood as arising from the same historical origins as under corporate reorganization law. Both Avon Park and Paradise Irrigation cite old equity receivership cases as well as corporate bankruptcy cases, showing that the rule in both contexts draws from the old "fair and equitable" principles first developed in the equity receivership cases. Thus, modern Chapter 9's direct incorporation of portions of Chapter 11 is fully consistent with the way municipal bankruptcy law historically overlapped with business bankruptcy law.

\section{B. Chapter 11 Case Law}

Because Congress incorporated Chapter 11's unfair discrimination rule into Chapter 9, this section of the article will explore how courts have interpreted this rule under Chapter 11. Although perhaps the Chapter 11 case law interpreting the unfair discrimination rule should not be controlling in Chapter 9 cases - an argument discussed and ultimately dismissed infra in Part IV - for this part of the article it is at least instructive to look at the Chapter 11 interpretation of the unfair discrimination.

When Congress added the unfair discrimination rule in section 1129 of the Bankruptcy Reform Act of 1978, this marked the first time in roughly 40 years that the unfair discrimination rule had been applicable in corporate bankruptcy. Congress had included the unfair discrimination rule in the very first corporate bankruptcy law in 1934, but it subsequently removed this rule a few years later. ${ }^{138}$ So when Congress re-introduced the unfair discrimination rule in creating Chapter 11 in 1978, there was not

136. II U.S.C. § 503(b)(1)(A) (2005).

137. 11 U.S.C. $\$ 328(2005)$.

138. See supra Part II. 
much prior case law to guide its application in Chapter 11. The legislative history of this rule provided little guidance, offering the unhelpful statement that " $[t]$ he criterion of unfair discrimination is not derived from the fair and equitable rule or from the best interests of creditors test." ${ }^{139}$ As Markell remarks, "This statement must be seen as odd, given Congress' remarks regarding municipal arrangements just two years earlier, in which unfair discrimination was said to be a derivative of the fair and equitable principle."140 The House Report goes on to provide examples of unfair discrimination in the situation of contractual subordination agreements, but the main point seems to be merely that the equally situated classes should receive equal treatment - a statement that provides no help in determining when discrimination reaches the point of unfairness. ${ }^{141}$

Because there was not extensive Chapter XI case law from which to draw, courts looked to case law interpreting the "unfair discrimination" language contained in Chapter 13's consumer debt composition rules, developing what has been called the Four Factor Test, discussed in detail below. This test was criticized by many courts as being unworkable, leading to the development of an alternative test has been widely adopted, based on an influential law review article by Bruce Markell. ${ }^{142}$ This test finds a rebuttable presumption of unfair discrimination whenever a dissenting class receives materially different treatment from a similarly situated class - a test sometimes referred to as the presumption-based approach or the Markell Test. Each of these two tests is discussed in order below. ${ }^{143}$

139. H.R. REP. No. 95-595, at 417 (1977).

140. Markell, supra note 17, at 236.

141. Supra note 139 , at 416-17.

142. Markell, supra note 17, at 242. Courts that have accepted Markell's test include: In re Armstrong World Indus., Inc., 348 B.R. 111, 122 (D. Del. 2006); In re Quay Corp., Inc., 372 B.R. 378, 386 (Bankr. N.D. Ill. 2007); In re Sentry Operating Co. of Texas, Inc., 264 B.R. 850, 863 (Bankr. S.D.Tex. 2001); In re Greate Bay Hotel \& Casino, Inc., 251 B.R. 213, 231-32 (Bankr. D.N.J. 2000); In re Dow Corning Corp., 244 B.R. 696, 702 (Bankr. E.D. Mich. 1999).

143. It should be noted there are two other ways some courts have interpreted the unfair discrimination rule, but they are outlier approaches. A few courts have simply applied a bright-line rule that any discrimination at all is per se unfair discrimination. See G. Eric Brunstad, Jr. \& Mike Sigal, Competitive Choice Theory and the Unresolved Doctrines of Classification and Unfair Discrimination, 55 BUS. LAWYER 1, 47 (1999) (citing In re Greystone III Joint Venture, 102 B.R. 560, 571 n.16 (Bankr. W.D.Tex. 1989)). Others have said that, since the legislative history discussing this rule did so in the context of subordination agreements, the unfair discrimination rule only applies if there is an intercreditor subordination agreement. See In re Acequia, Inc., 787 F.2d 1352, 1364 (9th Cir. 1986) (arguing that "the concept of unfair discrimination applies to plans in which claims or interests have been subordinated."). But because these two rules both elevate the legislative history of the rule over its text, and because they both render the word "unfairly" 


\section{Chapter 13-Derived Four-Factor Test}

The Four-Factor Test is derived from Chapter 13 case law interpreting the classification rule that permits consumer debtors to separately classify certain unsecured claims provided there is no unfair discrimination. ${ }^{144} \mathrm{~A}$ brief description of the Chapter 13 rule, consequently, is helpful for understanding the Chapter 11 case law.

Chapter 13 provides consumer debtors the option of entering a debt composition plan, which allocates the debtor's disposable income among its unsecured creditors on a pro rata basis. Under the old Chapter XIII, the debtor had to place all its unsecured creditors within the same class. ${ }^{145}$ Debtors struggled to complete such plans under Chapter XIII, in part because of the practical reality that a debtor might be under pressure to pay more than a pro rata portion to certain debts, such as debts shared with a co-debtor or debts that were non-dischargeable in bankruptcy. ${ }^{146}$ Since Chapter XIII did not provide for separate treatment for co-debts, a debtor would have to make additional payments outside the plan, thereby jeopardizing the debtor's ability to make all required payments under the plan. ${ }^{147}$

In response to this concern, Congress permitted debtors under Chapter 13 to "designate a class or classes of unsecured claims, as provided under section 1122 of this title, but may not discriminate unfairly against any class so designated." ${ }^{148}$ Congress later amended this to specifically address co-debts: "such plan may treat claims for a consumer debt of the debtor if an individual is liable on such consumer debt with the debtor differently than other unsecured claims." 149 The legislative history acknowledged that co-debtor claims are theoretically identical to other unsecured claims, but separate classification reflects the practical reality that a debtor will attempt

meaningless, this section will set these two aside as outlier interpretations.

144. Markell, supra note 17, at 242 (describing the four-part test developed from Chapter 13 cases).

145. See In re Wolff, 22 B.R. 510,514 (B.A.P. 9th Cir. 1982) (ruling that "Section 646 of the Bankruptcy Act governed plans under former Chapter XIII. While the plan could provide for secured creditors 'severally,' it required that unsecured creditors be provided for 'generally.' See, $\S 646(1)$, (2) of the Bankruptcy Act as amended. This was read to mean that all unsecured creditors were entitled to equal treatment. Collier on Bankruptcy, 14th Ed. Vol. 10, \28.02.").

146. S. REP. No. $98-65$, at 18 (1983) (noting that a rigid requirement that a Chapter 13 debtor make equal payments to all unsecured creditors may undermine the plan's feasibility).

147. Id.

148. 11 U.S.C. $\$ 1322(b)(1)(2010)$.

149. Id. The co-debtor provision was added in the Bankruptcy Amendments and Federal Judgeship Act of 1984, Pub. L. No. 98-353, § 316, 98 Stat. 333, 356 (1984). 
to make additional payments under co-debts. ${ }^{150}$ Allowing a debtor to make such payments under the plan makes it more likely that the debtor will in fact complete the plan. ${ }^{151}$ In contrast,"[a] result which emphasizes purity in classifying claims does so at the price of a realistic plan. Neither debtors nor creditors benefit from such a right approach." 152

Although "unfair discrimination" in Chapter 13 is a classification rule, i.e., it limits the debtor's ability to create separate classes of unsecured claims, classification in Chapter 13 has purely distributive consequences. This is because under Chapter 13, the classes of creditors do not vote on the debtor's proposed plan; rather, the classes exist as part of the proposed distribution framework. ${ }^{153}$ The debtor's plan must propose distributions to be made to each class, and all members within the class are required to receive the same distribution. ${ }^{154}$ So the only way to give different treatment to a group of creditors in Chapter 13 is to separately classify them.

Based on the policy that separate classification should be permitted in order to make it more feasible for the debtor to actually complete her payments under the composition plan, Chapter 13 courts developed the following four-factor test to determine whether separate classification amounted to unfair discrimination:

whether the discrimination has a reasonable basis;

whether the debtor can carry out a plan without the discrimination;

whether the discrimination is proposed in good faith; and

whether the degree of discrimination is directly related to the basis or rationale for the discrimination. ${ }^{155}$

Faced with the question of whether a Chapter 11 plan unfairly discriminates against a dissenting class of creditors, courts borrowed this Chapter 13 classification rule. ${ }^{156}$ Some courts, though, have noted that the four factors are redundant, as discrimination without a reasonable basis would appear to be in bad faith. ${ }^{157}$ Further, the plan itself must be proposed

150. 8 COLLIER ON BANKRUPTCY, 1322.05 (Allen N Resnick et al. eds., Lexis Nexis 16 th ed. 2014) (2014) (noting that "[a]lthough there may be no theoretical differences between co-debtor claims and others, there are important practical differences" that must be recognized) (quoting S. REP. No. 98-65, at 17-18 (1983)).

151. S. REP. NO. $98-65$, at 18 (1983).

152. Id.

153. 11 U.S.C. $\S 1325$ (2010) (setting forth the requirements of plan confirmation).

154. 11 U.S.C. $\S 1322(\mathrm{a})(3)(2010)$.

155. In re Leser, 939 F.2d 669, 672 (8th Cir. 1991).

156. In re Aztec Co., 107 B.R. 585, 590 (Bankr. M.D. Tenn. 1989).

157. In re Dow Corning Corp., 244 B.R. 696, 700-01 (Bankr. E.D. Mich. 1999) ("Although many courts have applied the four-factor test in chapter 11 cases to decide the unfair discrimination issue, some courts, finding its elements redundant, have pared it down 
in good faith, and so the unfair discrimination rule is not necessary to monitor the bona fides of the plan. ${ }^{158}$ Thus, some courts have boiled these four factors down to two questions (1) is there a rational basis for the discrimination? and (2) is the discrimination necessary for the reorganization? ${ }^{159}$

These two standards themselves are largely inter-related, as the necessity for the reorganization is itself a rational basis for the discrimination; that is, discrimination that is necessary for the reorganization per se has a rational basis. Thus, courts applying this test have found that discrimination has a rational basis when it is necessary to fulfill the Bankruptcy Code's best interests test, ${ }^{160}$ when the discrimination will protect an essential relationship with suppliers, ${ }^{161}$ and when discrimination in favor of vendors is necessary for the reorganization. ${ }^{162}$

\section{Markell Test}

In response to perceived theoretical and practical shortcomings of the Four-Factor Test, many courts have adopted an alternative test proposed by Bruce Markell in a highly influential law review article. ${ }^{163}$ Markell proposed a test that creates a rebuttable presumption of unfair discrimination whenever a plan treats a dissenting class of creditors materially differently than another class that shares the same distributional priority. ${ }^{164}$ The debtor can then rebut the presumption of unfair discrimination in two ways. First, the debtor can "prov[e] that the difference in treatment is attributable to differences in the prepetition status of the creditors." 165 That is, the discrimination is not unfair if the lower value (or increased risk) is consistent with the nature of the creditors'

to one or two factors.").

158. 11 U.S.C. $\$ 1129$ (a)(3) (2010).

159. In re Dow Corning, supra note 157 at 701 ..

160. In re 203 N. LaSalle St.P'ship, 190 B.R. 567, 586 (Bankr. N.D. Ill. 1995) aff'd sub nom. Bank of Am., Illinois v. 203 N. LaSalle St. P'ship, 195 B.R. 692 (N.D. Ill. 1996) aff'd sub nom. Matter of 203 N. LaSalle St. P'ship, 126 F.3d 955 (7th Cir. 1997) rev'd sub nom. Bank of Am. Nat'l Trust \& Sav. Ass'n v. 203 N. LaSalle St. P'ship, 526 U.S. 434, 119 S. Ct. 1411, 143 L. Ed. 2 d 607 (1999).

161. See AMFAC Distrib. Corp. v. Wolff, 22 B.R. 510 (B.A.P. 9th Cir. 1982) (showing separate classification for business debtor's insurance company and material suppliers may be permitted if debtor can show they are essential for debtor to continue in business).

162. In re Creekstone Apartments, 168 B.R. 639, 644 (Bankr. M.D. Tenn. 1994) ("Protection of the debtor's credit-worthiness with its vendors is vital to its successful reorganization.").

163. Markell, supra note 17, at 249-50.

164. Id.

165. Id at 250 . 
claims. Alternatively, the debtor can rebut the presumption of unfair discrimination by demonstrating "that contributions will be made by the assenting classes to the reorganization, and that these contributions are commensurate with the different treatment." 166 In other words, if the debtor can show that the favored class contributed offsetting new value, consistent with the Paradise Irrigation case under Chapter IX.

The Markell Test, sometimes referred to as the Presumption-Based Standard, was designed to address two perceived problems with the Four Factor Test. Primarily, it recognized that the Four Factors really boiled down to just this: "whether the proposed discrimination has a reasonable basis and is necessary for reorganization." may make sense in the Chapter 13 context in which there may be only one plan that the debtor is capable of confirming and carrying out, Markell argues that the concept of necessity is meaningless in the business bankruptcy Chapter 11 context: "Any nonindividual Chapter 11 case theoretically is capable of confirmation through plans which do not discriminate. ${ }^{" 168}$ As examples, he says:

a court could confirm a liquidation plan, or it could confirm a plan that extinguished all claims and interests, created one class of new equity interests, and then distributed those interests pro rata to creditors and equity holders. With such a plan, which could be confirmed in any case, discrimination is wholly absent. ${ }^{169}$

The second problem is that the Four Factor Test does not reflect the theory and function of the unfair discrimination rule (or of the cramdown requirements generally). The Four Factor Test, as stated above, is drawn from Chapter 13's unfair discrimination test, and the Chapter 13 test is one of creditor classification. The cramdown requirements, on the other hand, do not deal with classification; rather, they concern distribution. Classification is a question of voting procedure; the unfair discrimination and fair and equitable rules, in contrast, are distributional. As previously described, the distinction between classification and distribution is irrelevant in Chapter 13, as creditors do not vote on a plan of debt composition in that chapter. But in Chapter 11 , in which creditors do vote, classification and distribution questions are analytically distinct. Courts are

166. Id.

167. Id. at 243-44.

168. Id. at 254 .

169. Id. 
cognizant of this difference. ${ }^{170}$ contains some of the same elements as the tests for improper classification. ${ }^{171}$

Further, Markell contends that the Four Factor Test, with its focus on the necessity of the discrimination, improperly focuses on questions of plan feasibility, i.e., a question of whether the plan is likely to succeed. ${ }^{172}$ That is, the inquiry as to whether discrimination is necessary for a successful reorganization is really a question of whether the discrimination makes the plan more feasible than it would be without the discrimination. Feasibility questions, though, are separately handled under Section 1129(a)(11), which requires the court to find that the debtor is not likely to re-file for bankruptcy following confirmation. ${ }^{173}$

The Markell Test eschews this classification-type language and relative feasibility analysis. Instead, it proposes a test that reflects the old fair and equitable requirements' function of limiting a debtor's ability to allocate value in a way that disregarded the creditors' ex ante expectations, namely, that the creditors would be paid before stockholders (the absolute priority rule) and that creditors of the same priority level would receive the same treatment. These equitable principles also recognized that the debtor could nonetheless allocate value as compensation to creditors' contribution to the reorganization.

The Markell Test embodies these principles in the two ways in which a debtor can rebut the presumption of unfair discrimination: "If the treatment preserves the prebankruptcy expectations, or appropriately rewards contributions to reorganization, it should be permitted; if it unjustifiably frustrates those expectations, it should not." 74

Thus, the Markell Test recognizes that the different treatment may be

170. See e.g., In re U.S. Truck Co., 800 F.2d 581, 587 (6th Cir. 1986) ("Permitting separate classification of the Teamsters Committee's claim does not automatically result in adoption of the plan. The Teamsters Committee is still protected by the provisions of subsections (a) and (b), particularly the requirements of subsection (b) that the plan not discriminate unfairly and that it be fair and equitable with respect to the Teamsters Committee's claim."); see also, In re Lightsquared Inc., 513 B.R. 56, 88 (Bankr. S.D.N.Y. 2014) (noting that classification and unfair discrimination are separate issues that should be analyzed separately); Markell, supra note 17 at 241 ("Whether such discrimination 'discriminate[s] unfairly' against the noncontributing classes is an issue distinct from the propriety of the separate classification, and one upon which bankruptcy courts have not yet reached a consensus.").

171. See, e.g., In re Lightsquared, 513 B.R. at 83, 99 (examining whether there was a rational basis for separate classification and whether the allegedly discriminatory treatment was justified by a rational basis).

172. Markell, supra note 17 at 255.

173. 11 U.S.C. $\$ 1129$ (a)(11) (2010).

174. Markell, supra note 17, at 252-53. 
justified by examining the parties' expectations, suggesting, for example, that a plan might provide for a greater recovery for tort claimants over voluntary claimants, such as bondholders, because "there is every reason to believe that tort claimants have, if anything, a higher expectation of payment." 175 Likewise, different treatment may be justified to compensate creditors that are essential to the reorganization. For example, a plan may distribute more to a labor union if that union's good will is essential to the reorganization effort: "it is not unfair to return to that union more than its aliquot share of reorganization value since its efforts were responsible for the increase in that value." $" 176$

\section{Analysis: "Necessity" and "New Value"}

The Markell Test's structure is not only more workable and likely to yield more consistent results, but it is also, as Markell notes, more consistent with the traditional function and interpretation of the unfair discrimination rule. ${ }^{177}$ This rule is a distributional rule, providing a fundamental protection to dissenting classes of creditors, and it is not a classification rule. Thus, reference to Chapter 13's classification rule is slightly misplaced.

As far as providing a workable rule, the Markell Test reflects a superior approach. Instead of giving courts four redundant and, at times, self-referential factors to consider, the Markell Test provides a structure that reflects the purpose of the rule - to provide a baseline standard of equality among creditors - and justifications for deviating from this baseline.

Theoretically, the Markell Test also provides a rule that is more consonant with the function of the cram down requirements. Markell is absolutely right that classification questions should be treated separately from unfair discrimination questions. The Four Factor Test, which contains significant overlap with the general approach to handling improper classification arguments, conflates these issues, or at least threatens to do so. ${ }^{178}$

At the same time, though, the Markell Test shares some of the analytical shortcomings of the Four Factor Test. In both, it is nearly

175. Id. at 261 .

176. Id.

177. Id. at 257.

178. Some courts appear to have conflated these issues altogether, perhaps because the prevailing tests are so similar. See, e.g., In re City of Colorado Springs Spring Creek Gen. Imp. Dist., 187 B.R. 683, 689 (Bankr. D. Colo. 1995) (stating that issues of gerrymandering can and should be addressed as part of the "unfair discrimination" analysis of $\S 1129(\mathrm{~b})$ ). 
inevitable for the court to apply the unfair discrimination rule without considering the necessity of the discrimination or the feasibility of the plan. ${ }^{179}$ Even though the Markell Test seems to avoid the Four-Factor Test's inquiry into the necessity of the discrimination, ultimately, this necessity standard re-surfaces in the new value contribution analysis. Under the Four Factor Test, deviation from the principle of equality among creditors may be permitted if the court finds it is necessary to reorganize. ${ }^{180}$ Under the Markell Test, deviation may be acceptable if it reflects a new contribution from the favored class, and if the favored class's new contribution may be providing a service or value that is necessary to the reorganization effort. ${ }^{181}$ For example, when facing the question of whether a plan unfairly discriminates in favor of a class of creditors whose continued relationship with the debtor is important to the reorganization effort, it is necessary to determine whether the favored treatment is commensurate with the value of that continued relationship. ${ }^{182}$ Courts have applied the Four Factor Test to approve discrimination in favor of vendors when the "[p]rotection of the debtor's credit-worthiness with its vendors is vital to is successful reorganization." ${ }^{183}$ Likewise, a plan may discriminate in favor of a labor union when the debtor could not survive without the union and the discrimination "appears reasonably proportional to the consequences of failing to receive [the union's] support." ${ }^{184}$ The Markell test would likewise permit discrimination in these cases, as a plan that discriminates in favor of creditors whose continued work with the debtor may be considered a "contribution to preservation of value through the plan." 185 And Markell endorses the favored treatment for a key labor union:

If, for example, the good will of a key union is necessary for the profitability of the reorganized debtor, and that necessity is proved by the plan proponent, then it is not unfair to return to that union more than its aliquot share of reorganization value since its efforts were responsible for the increase in that value. ${ }^{186}$

179. See Pryor, supra note 9 (making a similar, but distinct, argument that the conflicting notions of requisite fairness under Chapter 9 serves a settlement inducing function).

180. See supra text accompanying notes $160160-162$

181. See supra text accompanying notes $174-176$

182. Markell, supra note 17 , at 250 .

183. In re Creekstone Apartments, 168 B.R. 639, 644 (Bankr. M.D. Tenn. 1994).

184. In re Kliegl Bros. Universal Elec. Stage Lighting, 149 B.R. 306 (Bankr. E.D.N.Y. 1992).

185. In re Sentry Operating Co. of Texas, 264 B.R. 850, 864 (Bankr. S.D. Tex. 2001).

186. Markell, supra note 17 , at 261. 
Thus, the Markell Test recognizes contributions to the reorganization effort not as "necessary to the reorganization" but as a contribution of value.

Even though the Markell Test, then, does not eliminate the necessity factor, it improves the analysis of this factor by placing it within the more familiar language and framework of the new value analysis - an analysis applied in Avon Park and Paradise Irrigation. Further, by placing the necessity analysis under the new value rule, the Markell Test also provides a theoretical limitation on the amount of permissible discrimination: the plan's discrimination must be proportional to the amount of the new value contribution.

In order to apply this theoretical limitation on the amount of discrimination, it is necessary to quantify the amount of that contribution. This problem has received significant attention as applied in the absolute priority context, i.e., when old shareholders contributed sufficient new value in order to justify their receiving value even when unsecured creditors are not paid in full. ${ }^{187}$ The absolute priority context is different in at least one important aspect; namely, Congress codified this rule in section 1129 (b)(2) but did not codify the unfair discrimination rule. ${ }^{188}$ The Supreme Court has intimated that, by codifying the absolute priority rule without mentioning the new value "rule," Congress thereby eliminated the new value rule altogether. ${ }^{189}$ Since Congress has not codified the unfair discrimination rule, there can be no similar argument that Congress intended to foreclose the new value contribution as applied to unfair discrimination.

Even assuming the new value rule continues to apply to the absolute priority rule, there has been substantial and significant debate over whether courts should apply a flexible or strict approach to measuring that new value contribution. ${ }^{190}$ Some have argued that the court should apply this rule more flexibly as needed to facilitate the debtor's reorganization. ${ }^{191}$ The argument is that the reorganized entity may not be able to succeed without the continuing input of the old owners. ${ }^{192}$ Others have argued that the rule should be applied narrowly, as a strict interpretation will help ensure that the residual class of claimants will ultimately make the decision

187. Baird, supra note 86 , at $584 \mathrm{n} .37$ (collecting cases and commentary about the new value corollary).

188. 11 U.S.C. $\$ 1129(b)(2)(2010)$.

189. Bank of Am. Nat'l Trust and Sav. Ass'n. v. 203 N. LaSalle St. P'ship, 526 U.S. 434 (1999); Norwest Bank Worthington v. Ahlers, 485 U.S. 197 (1988).

190. Baird, supra note 86 , at $584-85$.

191. Elizabeth Warren, $A$ Theory of the Absolute Priority, 1991 AnN. SERv. AM. L. 9 (1991).

192. Id. 
of whether the debtor should liquidate or reorganize. ${ }^{193}$

As David Skeel has argued, this uncertainty about the new value rule reflects the tension inherent in the two goals of corporate reorganization law - namely, "protection of creditors' rights and the promotion of a successful reorganization of the debtor."194 While in some cases these goals may overlap, in others they may very well diverge, and the Bankruptcy Code provides little guidance as to which goal should predominate. This normative question underlines a major split among bankruptcy theorists. ${ }^{195}$ The crux of this split is a policy question about who should have control over the allocation of the reorganization surplus, the debtor or the creditors. For those scholars who believe the primary goal of Chapter 11 is to maximize the value of the estate, creditors should have greater control over the allocation process. Specifically, control should be in the hands of the class of creditors holding the residual claims against the debtor. ${ }^{196}$ These scholars view strict adherence to the absolute priority rule as giving control to these residual claimants. For those scholars that believe the primary goal of bankruptcy is to facilitate the debtor's reorganization - thus reducing the impact of corporate failure on investors, suppliers, employees, and the community - the debtor should retain control over the allocation of the reorganization surplus and should be allowed to deviate from the absolute priority rule when necessary to improve the debtor's chance of recovery. ${ }^{197}$

These questions - both doctrinal and normative - apply equally in the unfair discrimination rule context. How courts should evaluate the asserted new value contribution raises the same issues in the unfair discrimination context as in the absolute priority context: to what degree should the plan proponents be free to deviate from a baseline distributional rule?

The Markell Test does not answer this question, leaving bankruptcy courts with substantial leeway in determining the amount of the asserted new value contribution. But by re-framing the "necessity" question as one of new value, this approach at least highlights the true nature of the necessity question and places it within a framework that is already relatively familiar to bankruptcy courts and the parties.

193. Baird, supra note 86 , at 583-84.

194. David A. Skeel, The Uncertain State of an Unstated Rule: Bankruptcy's Contribution Rule Doctrine After Ahlers, 63 AM. BANKR. L.J. 221, 223 (1989); see also Baird, supra note 86 at 584 ("This tension is reflected in the debate over what is called the 'new value exception' to the absolute priority rule.").

195. Baird, supra note 86 , at 583-84.

196. Id.

197. Id. 


\section{THE UNFAIR DiSCRIMINATION RULE IN CHAPTER 9}

There is good reason to think that unfair discrimination should mean the same thing in Chapter 9 as it does in Chapter 11 business reorganizations: the rule has the same historical roots in the two chapters and modern Chapter 9 directly incorporates the unfair discrimination rule from Chapter 11. At the same time, given the different nature of municipalities and their stakeholders (pensioners, in particular), one might credibly argue, as did the Detroit bankruptcy court, that the rule might apply differently in municipal bankruptcies. As discussed above, the Detroit confirmation order and opinion found the discrimination in favor of pensioners and bondholders to be fair "in light of, among other things, (a) the circumstances of the City's Chapter 9 Case, (b) the purpose of chapter 9, which is to adjust an insolvent municipality's debt so that it can provide adequate municipal services and (c) the Court's conscience, as informed by the Court's experience, education, and sense of morality." 198

In this section, I argue that, despite these mission-related and fairness concerns related to the vulnerability of municipal pensioners and other stakeholders, the unfair discrimination rule in municipal bankruptcy law should mean the same as it does in Chapter 11: the plan should not be able to treat one class of creditors substantially better than a similar class of dissenting creditors, unless that treatment comports with pre-bankruptcy expectations or reflects a new value contribution. Mission-related and fairness concerns should matter, if at all, only to the extent that they satisfy either of these two justifications for discrimination. Further, these missionrelated and fairness concerns are actually better addressed through this Chapter 11 approach.

\section{A. No Special Chapter 9 Unfair Discrimination Rule}

The statutory argument that the unfair discrimination rule should have the same meaning in Chapter 9 as in Chapter 11 is a simple and strong one: Chapter 9 directly incorporates the Chapter 11 rule into Chapter $9 .{ }^{199}$ When Congress intended Chapter 9 to vary from Chapter 11, it did so by either excluding specific provisions of Chapter 11 or by re-defining Chapter 11

198. Order Confirming Eighth Amended Plan for the Adjustment of Debts of the City of Detroit at 22, \21, In re City of Detroit Bankr., No. 13-53846, (Bankr. E.D. Mich. Nov. 12, 2014), available at http://www.mieb.uscourts.gov/sites/default/files/detroit/docket8272.pdf [hereinafter Order Confirming Eighth Amended Plan].

199. See 11 U.S.C. $§ 901$ (a) (2010) (incorporating Section 1129(b)(1)); see also Hynes \& Walt, Pensions \& Property Rights, supra note 9, at 637-38 (stating that Chapter 9 indirectly relies on the implicit standard of unfair discrimination because section 901(a) imports by reference 1129(b)(1)). 
concepts. For example, Chapter 9 incorporates the absolute priority rule as pertaining to secured and unsecured creditors but not as to equity holders. ${ }^{200}$ Chapter 9 also uses the "best interests of creditors" language but separately defines that in Section 943(b)(7), rejecting the Chapter 11 definition of that requirement. ${ }^{201}$ When Congress wanted to have a unique Chapter 9 rule, it explicitly did so, thus supporting a presumption that Congress did not intend a unique unfair discrimination rule. ${ }^{202}$

This approach is in accord with the historical usage of the unfair discrimination rule in municipal bankruptcies. The unfair discrimination rule was virtually identical in the original municipal and corporate bankruptcy laws, both drawing from the old fair and equitable principles developed in the equity receivership cases. ${ }^{203}$ And as seen in the Avon Park and Paradise Irrigation cases, courts used the business case law as support in interpreting the unfair discrimination rule under Chapter IX. ${ }^{204}$

At the same time, though, the historical usage of the unfair discrimination rule may be inapposite to modern municipal bankruptcy law under Chapter 9. Under the old Chapter IX, applicable to Avon Park and Paradise Irrigation, municipal bankruptcy served merely as a tool to impose a bond workout on dissenting bondholders. ${ }^{205}$ Even though a debtor under Chapter IX, in theory, could have impaired claims other than those of bondholders, the pre-arranged nature of Chapter IX bankruptcies made this practically impossible. So these cases considered only whether a debtor could discriminate among bondholders and never considered the question of value allocation among different classes of creditors. Thus, this case law may be of limited value as applied to Chapter 9, which gives debtors significantly more leeway to propose a plan that will impair the claims of other stakeholders, such as those of contract counterparties, employees, and retirees.

The relatively broader scope of current Chapter 9 than its predecessor Chapter IX supports a more flexible interpretation of unfair discrimination in modern municipal bankruptcies. David Skeel has opined that a court should have wide latitude in determining whether a plan favoring pensioners unfairly discriminates against bondholders and other unsecured creditors, arguing that the court should be free to take into account the

200. See 11 U.S.C. $\$ 901$ (a) (2010) (incorporating section 1129 (b)(2)(A) \& (B) but not section(C), the latter of which applies to equity holders).

201. 11 U.S.C. $\$ 943(b)(7)(2005)$.

202. Hynes \& Walt, Pensions \& Property Rights, supra note 9, at 637-38.

203. Supra part II.A.

204. Mason v. Paradise Irrigation Dist., 326 U.S 536, 541 (1946); Am. United Mut. Life Ins. Co. v. City of Avon Park, Fla., 311 U.S. 138, 147 (1940).

205. See supra Part III.A. 
financial impact of municipal bankruptcy law on pensioners. ${ }^{206}$ In Detroit, this would mean taking into account that the pensions were modest - not the sort of eye-brow raising pensions occasionally reported in California or elsewhere - that Michigan has elected to remove its public employees from the Social Security system, and that the pensioners were already giving up some of their medical benefits. ${ }^{207}$ Thus, the financial impact of impairing pensions would likely be greater than that of impairing bond obligations, arguably justifying better treatment for the pensioners than the bondholders.

These fairness considerations are extremely compelling, as pensioners are a sympathetic group of claimants; however, they are inconsistent with the way courts have applied the unfair discrimination rule under Chapter IX and in modern Chapter 11 cases. ${ }^{208}$ Historically, the rule has not focused on the characteristics of the favored stakeholders, even when those stakeholders are similarly sympathetic. ${ }^{209}$ Further, the history of the unfair discrimination rule and its current statutory formulation demonstrate Congressional intent that the rule have the same meaning in Chapters 9 and 11. That is, there is no support for creating a special Chapter 9 unfair discrimination rule.

This does not mean the fairness concerns are irrelevant; rather, it means those considerations are relevant only to the extent those considerations inform the inquiry into whether the discrimination comports with the parties' ex ante expectations or their new value contributions. Thus, discrimination in favor of pensioners is not fair because pensioners are a more vulnerable group; however, favoring pensioners may be justified if that outcome is consistent with the parties' ex ante expectations or with

206. Skeel, supra note 9, at 19 (arguing that " $[\mathrm{w}]$ ith the pensions, no unfair discrimination may allow Detroit to take into consideration the fact that Detroit's pensions are relatively modest, and that Detroit's pensioners are excluded from the social security system and thus do not have the same 'backup' protection as most other workers."). Note, though, that Judge Rhodes has stated multiple times in Detroit's bankruptcy that the retirees' hardship should not be a factor, and he reiterated that point in the opening arguments of the plan confirmation trial. See Nathan Bomey and Matt Helms, Attorney: 'Detroit Won't Recover' Without Grand Bargain, DETROIT FREE Press (Sept. 2, 2014), http://www.usatoday.com/story/news/nation/2014/09/02/detroit-bankruptcy-trial-what-toexpect/14952855/ (reporting on Detroit's chief bankruptcy lawyer's opening arguments for the plan of adjustment where he argues that pensioners be protected from severe cuts).

207. Skeel, supra note 9 , at 25 .

208. Hynes \& Walt, Pensions \& Property Rights, supra note 9, at 637 ("Our point is simply that, in other reorganization chapters, courts do not allow use of this standard to give priority to creditors who are at least as sympathetic. It is therefore reasonable to conclude that the unfair discrimination standard, as applied in Chapter 9, does not allow a plan to favor retirees based on their dire financial circumstances.").

209. Id. 
the resultant value to the estate.

The following section considers how the Markell Test - in particular the new value corollary - can more effectively address these fairness and mission-based concerns.

\section{B. Fairness and Mission-Based Concerns in the Markell Test}

The prior section argued that courts should apply the same unfair discrimination rule in both Chapters 9 and 11, despite the special policy concerns that arise under Chapter 9. This section contends that the fairness and mission-based concerns expressed by some commentators and by the Detroit confirmation order and opinion are better addressed through the Chapter 11 Markell Test. This approach provides greater predictability as to the application of the unfair discrimination rule; it provides an analytical tool for determining not merely whether discrimination may be appropriate but the acceptable degree of that discrimination; and it provides a better means of evaluating the claims of involuntary claimants, such as those in Detroit's class of Other Unsecured Creditors. ${ }^{210}$

The Markell Test takes into account fairness and mission-related concerns to the extent they are related to the parties' ex ante expectations or their contributions to the reorganization. For example, the pensioners and bondholders may both have understood that, in the event of default, pensioners would receive favored treatment based on the state constitutional protections for pensions. As with any expectation-based factor, there is a potential circularity to this argument: because courts are likely to be sympathetic to pensioners, bondholders should expect to receive less than pensioners in bankruptcy. But to the extent the parties' expectations are based on their expected treatment under state law, there is no circularity problem.

The mission-related concerns that motivated the Detroit bankruptcy court's interpretation of unfair discrimination may be encompassed, at least to some degree, in the new value corollary. For example, favoring pensioners may be justified in return for the pensioners' agreement to support the plan. Such a settlement may be a significant contribution to the debtor's ability to confirm a plan of adjustment. Likewise, favoring pensioners may be justified by the offsetting value to the city in retaining current employees and attracting future ones.

The benefit of analyzing fairness and mission-based concerns through the Markell Test is that is not only helps identify whether any discrimination would be fair but also how much discrimination would be

210. Supra note 100 (defining "Other Unsecured Creditors"). 
fair. The discrimination must be proportionate to the parties' state-lawbased expectations or their contributions. Thus, the Markell Test helps provide a limiting principle on the degree to which the debtor may discriminate.

This limiting principle, though, depends on the debtor's ability to quantify, at least approximately, the parties' expectations and new value contributions. As discussed supra in Part III.B.3, measuring the amount of any non-cash new value contribution is difficult, thus potentially undermining the benefit of any limiting principle. While the new value corollary has deep roots in municipal bankruptcy, the appropriate means for quantifying that new value contribution is unclear. Thus in Paradise Irrigation, the court held that the Reconstruction Finance Corporation was entitled to superior treatment under the plan because it had financed the plan. ${ }^{211}$ And in Avon Park, the court suggested that R.C. Crummer might be entitled to superior treatment for its services in negotiating the debt composition plan. ${ }^{212}$ Despite this long-held acceptance of the new value corollary in unfair discrimination cases, it is not clear how courts should measure the favored party's contributions.

As discussed in Part III.B.3, courts have examined this in Chapter 11 cases in the context of the absolute priority rule. Courts have interpreted the new value corollary in a narrow way, based on Congress's codification of the absolute priority rule in Section 1129(b)(2). ${ }^{213}$ This narrow interpretation in the absolute priority rule context also comports with the Chapter 11 policy of placing asset deployment decisions in the hands of the residual claimants. ${ }^{214}$

In the unfair discrimination analysis, there is obviously no similar statutory interpretation argument supporting a narrow reading of the new value corollary. Congress decided not to define unfair discrimination. In Chapter 9, the policy justification for a narrow reading is also weaker. The policy of Chapter 9 is to facilitate a city's debt restructuring to enable the city to continue providing services. Unlike Chapter 11 , there is no municipal bankruptcy policy of maximizing returns to creditors.

With this more straightforward policy goal, the interpretation of the new value rule is likewise more straightforward: it gives the debtor flexibility to depart from the Bankruptcy Code's vertical and horizontal limits on allocating the reorganization surplus.

This greater flexibility is not only consistent with Chapter 9's goals but also with its structure. Congress has consciously drafted municipal

211. Supra Part III.A(2).

212. Supra Part III.A(1).

213. Supra notes $188-189$ and accompanying text.

214. Baird, supra note 86 , at 586 . 
bankruptcy law to minimize federal intrusion into local municipal fiscal affairs, so as to avoid the constitutional concerns that led the Court to overturn the first municipal bankruptcy law. ${ }^{215}$ Greater flexibility, accordingly, is consistent with this "light touch" approach, as it gives debtor municipalities greater control over the surplus.

Leaving this control over the reorganization surplus in the hands of the bankrupt city is perhaps problematic. Some have argued that Chapter 9's "hands-off" approach to local governance could invite cities to strategically use bankruptcy in order to impose the costs of poor financial decisions on to creditors. ${ }^{216}$ Some have argued that courts can, and perhaps should, exercise more control over the debtor's resource allocation decisions. ${ }^{217}$ Even though the Code forbids such intrusion into local governance (absent consent by the city), these commentators have argued that courts can effectively assert control by strictly interpreting the confirmation requirements. ${ }^{218}$

Leaving aside the normative question of whether bankruptcy courts should have greater involvement in local governance of bankrupt cities, as a positive matter Congress has chosen to leave local governance in the

215. See Moringiello, supra note 20 at $410-11$.

216. Clayton P. Gillette, Fiscal Federalism, Political Will, and Strategic Use of Municipal Bankruptcy, 79 U. CHI. L. REV. 283, 285-86 (2012) (stating that "[p]erhaps less benignly, municipalities that could bear resource adjustments may refuse to fund obligations because residents regret having taken a risk that subsequently materialized and believe that relief from another source - a more centralized government or the creditors themselves-is plausible. Bailout or bankruptcy, that is, may be seen as a viable alternative to resource adjustments. Eric Monkkonen's study of late nineteenth-century municipal defaults, largely precipitated by overinvestment in railroad aid and other 'internal improvements,' concluded that localities systematically could afford to avoid default but preferred to impose the costs of imprudently incurred obligations on creditors rather than to require that residents bear them.").

217. Hynes \& Walt, supra note 9, Pensions \& Property Rights, at 624 (arguing that "[f]or this reason, the bankruptcy court in effect has the power to control the municipality's use of its assets to pay retirees. Thus, even if the court lacks the legal authority to control the municipality's spending, it can take measures that induce the municipality to limit its spending. In any realistic (practical) sense, the court has power over the municipality's use of its assets in a Chapter 9 case."); see also McConnell \& Picker, supra note 45, at 474 (pointing out that "[f]ederal bankruptcy courts have been explicitly denied any such powers. But in practice, the bankruptcy court may have more authority than at first appears. To be sure, the court may not order reductions in expenditure, sale of property, renegotiation of contracts, or increase in taxes. But the court can refuse to accept the city's debt adjustment plan on the ground that it is not in the 'best interests of the creditors.' This provision could be interpreted to mean that the city is capable of taking steps that would be more advantageous to the creditors than defaulting, and in most instances this probably means cutting spending, selling property, or raising taxes. Either of the first two interpretations would represent a stretch-at least as measured by the cases cited in the relevant legislative history-but ordering the levy of previously authorized taxes would not.").

218. Id. 
hands of the bankrupt city. A strict interpretation of unfair discrimination, then, is inconsistent with this chosen policy.

This does not mean, of course, that a municipal debtor is absolutely free to allocate value as it wishes, nor is this an argument that a debtor should be so free. A bankrupt city, like any Chapter 11 debtor, must be able to show that the discrimination is offset by new value from the favored party. The difference is that, due to the nature and scope of Chapter 9, courts should be more deferential to the city's judgment as to the value of the favored party's contribution.

\section{Application to Detroit}

Applying the Markell Test - along with the proposed flexible interpretation of the new value corollary - to Detroit's bankruptcy confirmation reveals that this test sufficiently, and in some ways more effectively, addresses many of the fairness and mission-related concerns underlying the Detroit court's opinion.

The court broadly stated that unfair discrimination is to be determined according to the court's judgment of its conscience regarding that discrimination." ${ }^{, 219}$ In elaborating on the factors that should inform that judgment, the court identified four: (1) the overall purpose of Chapter 9, (2) the policy preferences of the state, (3) the reasonable expectation of the parties, and (4) the interrelated nature of the settlements that facilitated the plan. ${ }^{220}$

The third factor neatly falls within the Markell Test framework by focusing on whether the discrimination is consistent with the parties' ex ante expectations. Likewise, the second factor - the policy preferences of the state - may also be understood as relating to the parties' expectations, as Michigan's constitutional pension protections would inform the parties' reasonable expectations.

The second factor, however, does more than this. It suggests that the court should defer to the distribution policies of the state of Michigan. ${ }^{221}$ This raises an interesting overall question about the relationship of federal and state law in municipal bankruptcy. Bankruptcy law generally does not honor state distribution rights, unless expressed as property rights. ${ }^{222}$

219. Oral Opinion on the Record of Judge Rhodes, supra note 15, at 29-30.

220. Id. at 30-32.

221. Id. at 31 .

222. See Skeel, supra note 36, at 2 ("As similar as liens and priorities are, the bankruptcy laws have long drawn a sharp distinction between state-created liens, which are honored in bankruptcy; and state-created priorities, which are not."); Hynes \& Walt, Pensions \& Property Rights, supra note 9, at 647 ("Congress was aware of the place of nonproperty based priorities under the original Bankruptcy Act and their restriction under the 
Municipal bankruptcy law might be different, however, since the Bankruptcy Code does not impose a distribution priority in Chapter 9, aside from administrative expense priorities. ${ }^{223}$ This point raises an important federalism issue outside the scope of this article; however, it is relevant in demonstrating the court's concern about interfering with local governance. That concern is consistent with the more flexible interpretation of the new value corollary, as advocated in Part IV.B.

The inter-related nature of the settlements undergirding the city's plan of adjustment also fits within the framework of the new value corollary. The settlements have a value to the estate that potentially justify any discrimination in favor of the settling parties.

The mission-based justification does not appear to fit at all in the Markell Test. This justification actually argues against incorporating any Chapter 11 case law into Chapter 9. The court's approach effectively introduces a necessity factor: discrimination is justified if it is necessary to allow the city to continue to provide services. Discrimination in favor of pensioners, then, is justified because it is an investment in the city's relationship with its employees; in contrast, the court held that the city "has no similar mission-related investment in its relationships with its other unsecured creditors., 224

In some ways, this mission-related factor is similar to the new value corollary. While the mission-related factor asks whether the discrimination will help the city continue to provide services, the new value approach asks whether the favored treatment compensates those who will contribute to the city's ongoing ability to provide services. The differences are potentially two-fold. As discussed in the prior section, the new value approach has the benefit of evaluating whether the extent of the discrimination is necessary. That is, the city can discriminate in favor of the contributing party, but only to the extent of the contribution's value.

The second difference is that the court's approach does not require that the benefitted party actually contribute anything; rather, the missionrelated justification merely asks whether the discrimination is related to the city's ability to continue providing services. Hence, the court did not say that the favored pensioners would actually help the city continue to provide services. Instead, the court found that favoring pensioners is consistent with city's interests in "preserving its relationships with its employees and

Chandler Act. It decided not to incorporate priorities set by state law into the Code and supplied instead a set of bankruptcy priorities. A fair inference is that current bankruptcy law does not recognize non-bankruptcy priorities that are not based on property rights.").

223. 11 U.S.C. $\$ 901$ (a) (2010) (incorporating by reference only the administrative priority found in $\S 507(\mathrm{a})(2))$.

224. Oral Opinion on the Record of Judge Rhodes, supra note 15, at 31. 
in enhancing their motivations."225

The new value approach, in contrast, may be read as requiring that the pensioners' themselves actually contribute the offsetting value. ${ }^{226}$ Since the pensioners are retired, the favored treatment is actually for work already performed, not for new contributions. ${ }^{227}$ Even under this interpretation of the new value rule, the pensioners contributed new value by withdrawing their objections to the bankruptcy, waiving claims against the state, and supporting the plan. In addition, a court may find that favoring the pensioners provides a goodwill value to the city, which in turn provides the benefits identified by the court. Indeed, this argument is implicit in the court's oral opinion, recognizing that favoring pensioners is important to the city's relationship with its workers. ${ }^{228}$

The Markell Test, then, would provide a more predictable approach for interpreting the unfair discrimination rule. It would also provide some limiting principle of the degree of the discrimination. Even more so, though, it would provide a better lens through which to analyze the claims of the tort claimants in the class of Other Unsecured Creditors. The court examines the objections of the tort claimants through the mission-based lens. Tort claimants, obviously, have no contribution to the city's ability to continue providing services. Under this approach, the debtor could propose to pay tort creditors only pennies on the dollar of their claims. Yet, Detroit's plan proposes to pay them approximately $13 \% .{ }^{229}$

The court's mission-based approach does not inform the question of whether this is an appropriate level of distribution, relative to the other classes of unsecured creditors. The court's approach can only say whether the city is justified in discriminating between classes of tort claimants, pensioners, and bondholders.

The Markell Test's expectations-based rule, on the other hand, might lead to a contrary conclusion. Tort creditors, obviously, did not voluntarily extend credit to the city, and thus it is a stretch to consider their expectations at the time they became creditors. Nonetheless, the expectation-based approach of the Markell Test might actually argue in favor of paying tort creditors even more than other creditors, as it is reasonable to believe that most people would expect that a tort victim

225. Id. at 30-31.

226. Hynes \& Walt, Fair \& Unfair Discrimination, supra note 9, at 16-17 (making the argument that: "The problem with the contribution justification is that the greater recovery received by many active and former workers will vastly exceed the contribution they make to the municipality's recovery. This is certainly true of retirees, as they contribute nothing to the city's reorganization; they have retired.").

227. Id.

228. Oral Opinion on the Record of Judge Rhodes, supra note 15, at 30-31.

229. Order Confirming Eighth Amended Plan, supra note 198, at 22, 120. 
would be paid in full if run over by a city bus. Thus, in the Chapter 11 context, Markell has argued that "there is every reason to believe that tort claimants have, if anything, a higher expectation of payment.",230

Tort claimants, however, are difficult to fit into any analysis, simply because of their nature as involuntary creditors. ${ }^{231}$ Nonetheless, the Markell Test provides a more workable structure for considering the claims of such creditors.

\section{CONCLUSION}

Although the unfair discrimination rule has largely operated in the shadows of the absolute priority rule in corporate reorganizations, Detroit's bankruptcy demonstrates that it is likely to play a significant role in shaping municipal debt readjustment plans. This is particularly so in cases in which the debtor seeks to impair its pension obligations.

Despite important differences between corporate reorganizations and municipal bankruptcies, this article contends that the unfair discrimination rule, as understood and articulated in the Markell Test, should apply equally in Chapter 9 as in Chapter 11. Although Chapter 9 raises a host of policy questions and fairness concerns that might not be relevant in most or any Chapter 11 cases, these concerns do not support creating a Chapter 9specific unfair discrimination rule. In both Chapters 9 and 11, the debtor should be able to discriminate in favor of a class of creditors only if that discrimination is proportionate to the favored party's ex ante expectations of payment or the party's ex post contribution of new value.

The Markell Test can effectively address municipal bankruptcy policy concerns if courts properly construe the new value corollary. While courts have interpreted this rule more narrowly in corporate bankruptcies in the context of the absolute priority rule, there is no statutory support for similarly interpreting the new value corollary narrowly in the unfair discrimination context. Further, while there may be some policy grounds for a narrow interpretation of new value in Chapter 11 even as applied to the unfair discrimination rule, the policy of Chapter 9 argues in favor of a more flexible interpretation.

Accordingly, even though Chapter 9 and Chapter 11 both use the same rule to prohibit unfair discrimination against a dissenting class of creditors, courts should grant greater deference to a municipal debtor's evaluation of creditors' contributions to the reorganization effort. This more flexible

230. Markell, supra note 17, at 261.

231. Melissa Jacoby, Detroit's Bankruptcy: End(s) and Means, CredIT SLIPS (Nov. 10, 2014) http://www.creditslips.org/creditslips/2014/11/detroits-restructuring-ends-andmeans.html\#more. 
approach to applying the unfair discrimination rule is consistent with the structure of Chapter 9 and the policy underlying it, as Congress has deliberately crafted municipal bankruptcy law to limit federal interference in municipal governance. Such a deferential approach also advances the purpose of Chapter 9, which is to enable a municipal debtor to confirm a plan of debt adjustment with its creditors in order to continue providing services to its residents.

Properly construed, the Markell Test can more effectively evaluate the fairness of a debtor's proposed discrimination, providing not only a framework for identifying when discrimination may be appropriate but also a framework for identifying how much discrimination may be appropriate. Further, the Markell Test provides a superior framework for evaluating the relative distributions among not only pensioners and bondholders, but also involuntary creditors. 